\title{
Update on genetics and diabetic retinopathy
}

This article was published in the following Dove Press journal:

Clinical Ophthalmology

23 November 2015

Number of times this article has been viewed

\author{
Blake M Hampton' \\ Stephen G Schwartz' \\ Milam A Brantley J ${ }^{2}$ \\ Harry W Flynn Jr' \\ 'Department of Ophthalmology, \\ Bascom Palmer Eye Institute, \\ University of Miami Miller School \\ of Medicine, Miami, FL, USA; \\ ${ }^{2}$ Department of Ophthalmology, \\ Vanderbilt Eye Institute, Nashville, \\ TN, USA
}

\begin{abstract}
Clinical risk factors for diabetic retinopathy (DR), such as duration of disease and degree of glucose control, do not adequately predict disease progression in individual patients, suggesting the presence of a genetic component. Multiple smaller studies have investigated genotype-phenotype correlations in genes encoding vascular endothelial growth factor, aldose reductase, the receptor for advanced glycation end products, and many others. In general, reported results have been conflicting, due to factors including small sample sizes, variations in study design, differences in clinical end points, and underlying genetic differences between study groups. At this time, there is no confirmed association with any risk allele reported. As we continue to collect data from additional studies, the role of genetics in DR may become more apparent.
\end{abstract}

Keywords: diabetic retinopathy, genetics, single nucleotide polymorphism, genome-wide association study

\section{Introduction}

Diabetic retinopathy (DR) is the leading cause of blindness in the US affecting people between the ages of 20 and 74 years $^{1}$ and is a prominent cause of visual impairment in the developing world. ${ }^{2}$ Increased duration of diabetes, ineffective blood glucose control, and ineffective blood pressure control are the major risk factors for DR. ${ }^{3}$ However, the incidence and progression of DR among patients with similar metabolic factors may vary substantially. ${ }^{4}$ Furthermore, race, ethnicity, and sex appear to correlate with rates of DR. In the US, DR has been reported to be "slightly more prevalent" in men than in women $(P=0.04),{ }^{5}$ but this finding has not been replicated on a worldwide scale. ${ }^{6}$ All races and ethnicities are affected by DR, but some populations might be at higher risk. In the US, African-Americans and Hispanics have significantly higher reported rates of DR than non-Hispanic whites; ${ }^{7}$ for example, in one series, non-Hispanic blacks had significantly higher rates than non-Hispanic whites of DR $(P=0.01)$ and vision-threatening DR $(P=0.01) .{ }^{5}$ Reports on multiple populations from multiple nations suggest that African/Afro-Caribbean, South Asian, Latin American, and indigenous tribal populations have relatively higher rates of DR; the differences achieved statistical significance in some but not all of these studies. ${ }^{7,8}$ Taken together, these findings suggest a genetic influence on the development and progression of DR. Heritability has been estimated as high as $27 \%$ for DR and $52 \%$ for proliferative diabetic retinopathy (PDR). ${ }^{9-11}$

This manuscript attempts to review the present literature regarding associations between various gene variants and DR. PubMed was searched using the terms “(((“2012/01/01”[Date - Publication]: “3000”[Date - Publication])) AND (Diabetic AND Retinopathy)) AND Genetics" so that articles published following a previous review article on this subject ${ }^{12}$ would be included. The intent was to create a relatively concise review to give the practicing clinician an appreciation
Correspondence: Stephen G Schwartz Department of Ophthalmology, Bascom Palmer Eye Institute, University of Miami Miller School of Medicine, 3880 Tamiami Trail North, Naples, FL 34103, USA

$\mathrm{Tel}+\mathrm{I} 2396593937$

Fax + I 2396593984

Email sschwartz2@med.miami.edu 
for the current knowledge regarding genetic contributors to DR. This is not an all-inclusive document and it is likely that other genes and polymorphisms that have been studied with respect to DR have been missed by the search strategy.

Most genotype-phenotype studies of DR have used either individual candidate gene analyses or systematic genomewide association studies. ${ }^{13}$ Many gene variants have been studied for possible associations with DR. These include well-studied genes (Table 1) that are believed to contribute to the pathogenesis of diabetes or DR, as well as many more recently described and less understood gene variants (Table 2), as well as genes for which no positive associations have been reported (Table 3 ).

\section{Well-studied candidate genes}

Four well-studied candidate genes, which encode proteins that are believed to be important in the pathogenesis of diabetes or DR, include vascular endothelial growth factor $(V E G F)$, receptor for advanced glycation end products ( $R A G E)$, endothelial nitric oxide synthase (eNOS), and aldose reductase $(A R)$.

Table I Well-studied candidate gene studies and findings

\begin{tabular}{|c|c|c|c|c|c|}
\hline Gene & Polymorphism & $\begin{array}{l}\text { Relation to diabetic } \\
\text { retinopathy and significance } \\
\text { level }\end{array}$ & $\begin{array}{l}\text { Population and size } \\
\text { (number of participants) }\end{array}$ & $\begin{array}{l}\text { Methodology } \\
\text { (self-reported vs } \\
\text { clinically assessed) }\end{array}$ & References \\
\hline \multirow[t]{3}{*}{$\overline{A R}$} & $\begin{array}{l}\mathrm{C}(-106) \mathrm{T} \text {, specifically } \\
\mathrm{CC} \text { genotype }\end{array}$ & $\begin{array}{l}\text { Positive assn } w / D R \text { in T2DM } \\
(P=0.03)\end{array}$ & Iranian (206 pts) & Clinically assessed & 27 \\
\hline & $C(-106) T$ & No sig assn w/ DR in T2DM & Chinese (268 pts) & Clinically assessed & 28 \\
\hline & $\mathrm{C}(-106) \mathrm{T}, \mathrm{C}$ allele & $\begin{array}{l}\text { No sig assn w/ NPDR or PDR } \\
\text { in T2DM } \\
\text { Positive assn w/ DR in TIDM } \\
(\mathrm{OR}=1.78,95 \% \mathrm{Cl}=1.39-2.28)\end{array}$ & $\begin{array}{l}\text { Meta-analysis of } 17 \text { studies } \\
\text { including multiple populations } \\
(7,83 \text { I pts) }\end{array}$ & $\begin{array}{l}\text { Clinically assessed in } \\
\text { all included studies } \\
\text { except two, which did } \\
\text { not report how DR } \\
\text { was determined in pts }\end{array}$ & 29 \\
\hline \multirow[t]{15}{*}{ eNOS } & VNTR 4b/a, a allele & $\begin{array}{l}\text { Negative assn w/ DR (8 studies } \\
=\text { T2DM, I study = TIDM; } \\
P=0.005 \text { ); no sig assn w/ PDR }\end{array}$ & $\begin{array}{l}9 \text { studies for NOS3 4b/a } \\
\text { polymorphism (3,145 pts) }\end{array}$ & Not reported & 31 \\
\hline & rs2070744 (786T/C) & $\begin{array}{l}\text { No sig assn } w / \text { DR or PDR } \\
\text { (4 studies = T2DM, } \\
\text { I study = TIDM) }\end{array}$ & $\begin{array}{l}5 \text { studies for NOS3 T-786C } \\
\text { polymorphism }(2,147 \mathrm{pts})\end{array}$ & & \\
\hline & $\begin{array}{l}\text { rsl799983 (894G/T, } \\
\text { also Glu298Asp) }\end{array}$ & $\begin{array}{l}\text { No sig assn w/ DR or PDR } \\
\text { in T2DM }\end{array}$ & $\begin{array}{l}7 \text { studies for NOS3 G894T } \\
\text { polymorphism ( } 2,819 \text { pts) } \\
\text { Meta-analysis of I } 2 \text { studies } \\
\text { including multiple populations } \\
\text { ( } 8,1 \text { II pts) }\end{array}$ & & \\
\hline & VNTR 4b/a, aa genotype & $\begin{array}{l}\text { Negative assn w/ PDR }(P=0.03) \\
\text { but no sig assn } w / D R \text { in T2DM }\end{array}$ & Asian Indian (I,446 pts) & Clinically assessed & 32 \\
\hline & rs2070744 (786T/C), & No sig assn w/ DR or PDR & & & \\
\hline & CC genotype & in T2DM & & & \\
\hline & $\begin{array}{l}\text { rs I799983 (894G/T, also } \\
\text { Glu298Asp), TT genotype }\end{array}$ & $\begin{array}{l}\text { No sig assn w/ DR or PDR } \\
\text { in T2DM }\end{array}$ & & & \\
\hline & VNTR 4b/a, aa genotype & $\begin{array}{l}\text { Negative assn w/ DR in T2DM } \\
\text { (OR }=0.75,95 \% \mathrm{Cl}=0.65-0.88 \text { ) } \\
\text { in Africans ( } 2 \text { studies) but not } \\
\text { Caucasians ( } 4 \text { studies) or Asians } \\
\text { (10 studies) }\end{array}$ & $\begin{array}{l}\text { Meta-analysis of } 16 \text { studies } \\
\text { including multiple populations } \\
(6,664 \mathrm{pts})\end{array}$ & Not reported & 33 \\
\hline & VNTR 4b/a, a allele & $\begin{array}{l}\text { Positive assn w/ PDR } \\
\text { in T2DM }(P=0.01)\end{array}$ & Slovenian (577 pts) & Clinically assessed & 34 \\
\hline & $\begin{array}{l}\text { rs I799983 (894G/T, also } \\
\text { Glu298Asp), GG genotype }\end{array}$ & No sig assn w/ PDR in T2DM & & & \\
\hline & VNTR 4b/a, aa genotype & $\begin{array}{l}\text { No sig assn w/ DR or PDR } \\
\text { in T2DM }\end{array}$ & Caucasian-Brazilian (630 pts) & Clinically assessed & 35 \\
\hline & rs2070744 & No sig assn w/ DR or PDR & & & \\
\hline & (786T/C) genotype & in T2DM & & & \\
\hline & rsI799983 (894G/T, also & No sig assn w/ DR or PDR & & & \\
\hline & Glu298Asp) genotype & in T2DM & & & \\
\hline
\end{tabular}


Table I (Continued)

\begin{tabular}{|c|c|c|c|c|c|}
\hline Gene & Polymorphism & $\begin{array}{l}\text { Relation to diabetic } \\
\text { retinopathy and significance } \\
\text { level }\end{array}$ & $\begin{array}{l}\text { Population and size } \\
\text { (number of participants) }\end{array}$ & $\begin{array}{l}\text { Methodology } \\
\text { (self-reported vs } \\
\text { clinically assessed) } \\
\end{array}$ & References \\
\hline & VNTR 4b/a, aa genotype & No sig assn w/ DR in T2DM & South Indian (3II pts) & Clinically assessed & 36 \\
\hline & rs2070744 (786T/C) & No sig assn w/ DR in T2DM & & & \\
\hline & genotype & & & & \\
\hline & rsl $799983(894 \mathrm{G} / \mathrm{T}$, also & No sig assn w/ DR in T2DM & & & \\
\hline & Glu298Asp) genotype & & & & \\
\hline & VNTR 4b/a genotype & No sig assn w/ DR in T2DM & $\begin{array}{l}\text { Meta-analysis of } 15 \text { studies } \\
\text { including multiple populations } \\
\text { (6,593 pts) }\end{array}$ & Not reported & 37 \\
\hline \multirow[t]{14}{*}{ RAGE } & $-429 \mathrm{~T} / \mathrm{C}$ in promoter region & No sig assn w/ DR in T2DM & Malaysian (577 pts) & Clinically assessed & 39 \\
\hline & $\begin{array}{l}-374 T / A \text { in promoter } \\
\text { region }\end{array}$ & No sig assn w/ DR in T2DM & & & \\
\hline & $\begin{array}{l}-429 T / C \text { in promoter } \\
\text { region }\end{array}$ & No sig assn w/ DR in T2DM & $\begin{array}{l}\text { Asian and Caucasian }-6 \text { studies } \\
(2,317 \text { pts })\end{array}$ & Clinically assessed & 40 \\
\hline & $-374 \mathrm{~T} / \mathrm{A}$ in promoter & Negative assn w/ DR in T2DM & Asian, African, and Caucasian & & \\
\hline & region, $\mathrm{AA}$ genotype & $(\mathrm{OR}=0.64,95 \% \mathrm{Cl}=0.42-0.99)$ & -7 studies (3,339pts) & & \\
\hline & Gly82Ser, $82 \mathrm{~S}$ allelic variant & No sig assn w/ DR in T2DM & $\begin{array}{l}\text { Asian }-5 \text { studies (I,9II pts) } \\
\text { (meta-analysis of II studies) }\end{array}$ & & \\
\hline & Gly82Ser, Ser82 genotype & $\begin{array}{l}\text { Sig assn w/ DR in T2DM } \\
(P<0.033)\end{array}$ & North Indian (758 pts) & Clinically assessed & 41 \\
\hline & Gly82Ser in exon 3 & No sig assn w/ DR in T2DM & Malaysian (283 pts) & Clinically assessed & 42 \\
\hline & $1704 \mathrm{G} / \mathrm{T}$ in intron 7 & No sig assn w/ DR in T2DM & & & \\
\hline & $2184 \mathrm{~A} / \mathrm{G}$ in intron 8 & No sig assn w/ DR in T2DM & & & \\
\hline & Gly82Ser in exon 3 & No sig assn w/ DR in T2DM & Caucasian, Asian, African & Not reported & 43 \\
\hline & & & $\begin{array}{l}\text { American (meta-analysis of } 29 \\
\text { studies - } 1000+\text { pts) }\end{array}$ & & \\
\hline & $1704 \mathrm{G} / \mathrm{T}$ in intron 7 & No sig assn w/ DR in T2DM & & & \\
\hline & $429 \mathrm{~T} / \mathrm{C}$ in promoter region & No sig assn w/ DR in T2DM & & & \\
\hline \multirow[t]{25}{*}{ VEGF } & rs83306I $(-460 \mathrm{C} / \mathrm{T})$ & Positive assn w/ PDR in T2DM & Asian (Indian, Bengali Hindu & Clinically assessed & 44 \\
\hline & C allele & $(P=0.0043)$ & -493 pts) & & \\
\hline & rs83306I $(-460 \mathrm{C} / \mathrm{T})$ & Negative assn w/ PDR in T2DM & & & \\
\hline & TT genotype & $(P=0.0126)$ & & & \\
\hline & rs699947 (-2578 A/C) & $\begin{array}{l}\text { No sig assn w/ DR in DM } \\
\text { (studies include TIDM + T2DM) }\end{array}$ & $\begin{array}{l}\text { Asian and Caucasian: } \\
6 \text { studies (2,208 pts) }\end{array}$ & Clinically assessed & 45 \\
\hline & rs83306I (-460T/C) & Positive assn $w / D R(P=0.02)$ & Asian and Caucasian: & & \\
\hline & C allele & and PDR $(P=0.02)$ in T2DM & 6 studies (I,654 pts) & & \\
\hline & & & $\begin{array}{l}\text { (meta-analysis of II studies; one } \\
\text { study examined both SNPs) }\end{array}$ & & \\
\hline & rs2010963 (-634G/C) & No sig assn w/ DR in T2DM & Asian and Caucasian: & Not reported & 46 \\
\hline & & & 7 studies $(2,104$ pts $)$ & & \\
\hline & rs699947 (-2578C/A) & No sig assn w/ DR in T2DM & Asian and Caucasian: & & \\
\hline & & & 6 studies ( 1,868 pts) & & \\
\hline & rs3025039 (+936C/T) & $\begin{array}{l}\text { Positive assn } w / D R \text { in T2DM } \\
(P=0.0 \mathrm{I})\end{array}$ & Asian only: 4 studies (I,I47 pts) & & \\
\hline & rs83306I (-460T/C) & Positive assn w/ DR in T2DM & Asian only: 3 studies (746 pts) & & \\
\hline & & $(P=0.02)$ & (meta-analysis of II studies) & & \\
\hline & rs20I0963 (-634 G/C) & No sig assn w/ DR/PDR in T2DM & Han Chinese (376 pts) & Clinically assessed & 47 \\
\hline & rs83306I $(-460 \mathrm{C} / \mathrm{T})$ & Negative assn w/ NPDR & & & \\
\hline & $\mathrm{C}$ allele/CC genotype & ( $P=0.013$ for genotype, $P=0.002$ & & & \\
\hline & & for allele) but no sig assn & & & \\
\hline & & $w / P D R$ in T2DM & & & \\
\hline & rs699947 (-2578C/A) & $\begin{array}{l}\text { Positive assn } w / D R \text { in T2DM } \\
(\mathrm{OR}=3.54,95 \% \mathrm{Cl}=1.12-11.19)\end{array}$ & Chinese (500 pts) & Clinically assessed & 48 \\
\hline & rs|320735| & Positive assn w/ DR in T2DM & & & \\
\hline & & $(\mathrm{OR}=3.76,95 \% \mathrm{Cl}=|.2 \mathrm{I}-| \mathrm{I} .7 \mathrm{I})$ & & & \\
\hline & rs83306I $(-460 \mathrm{C} / \mathrm{T})$ & No sig assn w/ DR in T2DM & & & \\
\hline & rs2146323 & No sig assn w/ DR in T2DM & & & \\
\hline
\end{tabular}

(Continued) 
Table I (Continued)

\begin{tabular}{|c|c|c|c|c|c|}
\hline Gene & Polymorphism & $\begin{array}{l}\text { Relation to diabetic } \\
\text { retinopathy and significance } \\
\text { level }\end{array}$ & $\begin{array}{l}\text { Population and size } \\
\text { (number of participants) }\end{array}$ & $\begin{array}{l}\text { Methodology } \\
\text { (self-reported vs } \\
\text { clinically assessed) }\end{array}$ & References \\
\hline & rs699947 (-2578 A/C) & $\begin{array}{l}\text { Positive assn w/ DR (type not } \\
\text { specified) in T2DM ( } P=0.003)\end{array}$ & $\begin{array}{l}\text { Asians and Europeans: } \\
8 \text { studies ( } 2,402 \text { pts) }\end{array}$ & Not reported & 49 \\
\hline & rs2010963 (+405 G/C) & $\begin{array}{l}\text { No sig assn w/ DR or PDR } \\
\text { in T2DM }\end{array}$ & $\begin{array}{l}\text { Asians and Europeans: } \\
10 \text { studies ( } 3,448 \text { pts) } \\
\text { (meta-analysis of } 18 \text { studies } \\
\text { total) }\end{array}$ & & \\
\hline & $\begin{array}{l}\text { rs699947 }(-2578 \mathrm{C} / \mathrm{A}) \\
\text { AA genotype }\end{array}$ & $\begin{array}{l}\text { Positive assn w/ DR in T2DM in } \\
\text { Asian }(P=0.0002) \text { pts but not in } \\
\text { Caucasian pts }\end{array}$ & $\begin{array}{l}\text { Asian and Caucasian (meta- } \\
\text { analysis of } 6 \text { studies - I,702 } \\
\text { pts; I, I } 24 \text { of which were Asian) }\end{array}$ & Not reported & 50 \\
\hline & rs699947 (-2578 A/C) & $\begin{array}{l}\text { No sig assn w/ DR unless } \\
\text { diabetes duration of } 20+\text { years } \\
(P<0.00 \text { I) (Type of DM not } \\
\text { specified) }\end{array}$ & Egyptian (I48 pts) & Clinically assessed & 51 \\
\hline & rs699947 (-2578 A/C) & No sig assn w/ DR in T2DM & Chinese (I,040 pts) & Clinically assessed & 52 \\
\hline & $\mathrm{rs} 2010963(+405 \mathrm{C} / \mathrm{G})$ & No sig assn w/ DR in T2DM & & & \\
\hline & rs3025039 (+936C/T) & No sig assn w/ DR in T2DM & & & \\
\hline & rsI570360 (-II54 G/A) & $\begin{array}{l}\text { No sig assn w/ NPDR } \\
\text { or PDR in T2DM }\end{array}$ & Bengali Hindu (372 pts) & Clinically assessed & 53 \\
\hline & rs3025039 (+936 C/T) & Positive assn $w /$ PDR $(P=0.0002)$ & & & \\
\hline & T allele & but not NPDR in T2DM & & & \\
\hline & rs20I0963 (+405 G/C) & Positive assn $w /$ PDR $(P=0.0007)$ & & & \\
\hline & C allele & but not w/ NPDR in T2DM & & & \\
\hline & rs207I559 (R 2/KDR-604 & No sig assn w/ NPDR & & & \\
\hline & $\mathrm{A} / \mathrm{G})$ & or PDR in T2DM & & & \\
\hline & $\begin{array}{l}\text { rs2010963 }(-634 \mathrm{G} / \mathrm{C}) \\
\text { C allele }\end{array}$ & $\begin{array}{l}\text { Positive assn } w / D R \text { in T2DM } \\
(P=0.03)\end{array}$ & $\begin{array}{l}\text { Meta-analysis of } 9 \text { studies } \\
\text { including multiple populations } \\
(2,947 \text { pts })\end{array}$ & Clinically assessed & 54 \\
\hline & rs6921438 & No sig assn $w / D R$ in T2DM & French $(2,567 \mathrm{pts})$ & Clinically assessed & 55 \\
\hline & rs 10738760 & No sig assn $w / D R$ in T2DM & & & \\
\hline
\end{tabular}

Abbreviations: AR, aldose reductase; eNOS, endothelial nitric oxide synthase; VNTR, variable number tandem repeat; RAGE, receptor for advanced glycation end products; VEGF, vascular endothelial growth factor; PDR, proliferative diabetic retinopathy; NPDR, nonproliferative diabetic retinopathy; KDR, kinase insert domain receptor; T2DM, type 2 diabetes mellitus; TIDM, type I diabetes mellitus; SNP, single nucleotide polymorphism; DR, diabetic retinopathy; OR, odds ratio; CI, confidence interval; assn, association; sig, significant; pts, participants; w/, with.

\section{AR}

AR converts glucose to sorbitol in the polyol pathway; ${ }^{14}$ sorbitol cannot cross cell membranes but can accumulate in insulin-independent tissues, where it draws in water and produces osmotic stress. ${ }^{15}$ Multiple studies have reported conflicting results regarding a potential association between $A K R 1 B 1$ and DR. ${ }^{16-26}$ For example, the $\mathrm{C}(-106) \mathrm{T}$ polymorphism was significantly associated with DR in a series of 206 Iranian patients with type 2 diabetes $(P=0.03)^{27}$ but not in a series of 268 Chinese patients with type 2 diabetes. ${ }^{28}$ A meta-analysis of 7,831 patients from 17 studies from Asia, South America, Europe, and Australia reported a significant association between the $\mathrm{C}(-106) \mathrm{T}$ polymorphism and DR in patients with type 1 diabetes (odds ratio $[\mathrm{OR}]=1.78,95 \%$ confidence interval $[\mathrm{CI}]=1.39-2.28)$ but not type $2 .{ }^{29}$

\section{eNOS}

eNOS is involved in regulating vascular tone by inhibiting smooth muscle contraction and platelet aggregation. ${ }^{30}$ Two studies (both including patients with type 1 and type 2 diabetes), a meta-analysis including nine studies comprising 3,145 patients from multiple nations, ${ }^{31}$ and one including 1,446 Asian Indian patients, ${ }^{32}$ reported that the $4 \mathrm{a}$ allele of a variable number tandem repeat (VNTR) in the gene was negatively associated with $\mathrm{DR}(P=0.005)^{31}$ and PDR $(P=0.03) .{ }^{32}$ Another meta-analysis of 16 studies comprising 6,664 patients reported that the AA genotype of 27VNTR $(4 \mathrm{a} / \mathrm{b})$ was negatively associated with DR in type 2 diabetes $(\mathrm{OR}=0.75,95 \% \mathrm{CI}=0.65-0.88)$, but only in African populations (of note, the analysis included two studies containing a total of 1,447 patients of African ancestry from the US and Tunisia) and not in Caucasian or Asian populations. ${ }^{33}$ 
Table 2 Newer candidate gene studies and findings

\begin{tabular}{|c|c|c|c|c|c|}
\hline Gene & Polymorphism & $\begin{array}{l}\text { Relation to diabetic } \\
\text { retinopathy and } \\
\text { significance level }\end{array}$ & $\begin{array}{l}\text { Population and } \\
\text { size (number of } \\
\text { participants) }\end{array}$ & $\begin{array}{l}\text { Methodology } \\
\text { (self-reported vs } \\
\text { clinically assessed) }\end{array}$ & References \\
\hline \multirow{5}{*}{$\begin{array}{l}\text { Adiponectin } \\
\text { (ADIPOQ) }\end{array}$} & rs224I766 (T45G) & Positive assn $\mathrm{w} / \mathrm{DR}$ in T2DM & Indian - NW population & Clinically assessed & 57 \\
\hline & $\begin{array}{l}\text { T allele } \\
\text { rs266729 (C-I I377G) }\end{array}$ & $\begin{array}{l}(P=0.0007) \\
\text { No sig assn } w / D R \text { in T2DM }\end{array}$ & $\begin{array}{l}\text { of Punjab - (672 pts) } \\
\text { Chinese (517 pts) }\end{array}$ & Clinically assessed & 58 \\
\hline & rs822394 (A-4034C) & No sig assn w/ DR in T2DM & & & \\
\hline & rsI50I299 (G276T) & No sig assn w/ DR in T2DM & & & \\
\hline & rs224I766 (T45G) & No sig assn w/ DR in T2DM & & & \\
\hline \multirow{10}{*}{$\begin{array}{l}\text { CFH and } \\
\text { CFB }\end{array}$} & rs I048709 (RI50R) & Positive assn $\mathrm{w} / \mathrm{DR}$ in T2DM & Chinese (552 pts) & Clinically assessed & 61 \\
\hline & A allele in CFB & $(P=0.035)$ & & & \\
\hline & rs800292 (I62V) A allele & Negative assn w/ DR in & & & \\
\hline & in $\mathrm{CFH}$ & T2DM $(P=0.04)$ & & & \\
\hline & rs537I 60 (IVS7) & No sig assn w/ DR in T2DM & & & \\
\hline & $\mathrm{G}>\mathrm{A}$ in $\mathrm{CFB}$ & & & & \\
\hline & rs4I5I657 (IVSI0) T> & No sig assn w/ DR in T2DM & & & \\
\hline & $C$ in $C F B$ & & & & \\
\hline & rs2072633 (IVSI7) A > & No sig assn w/ DR in T2DM & & & \\
\hline & $\begin{array}{l}\mathrm{G} \text { in CFB } \\
\mathrm{rs} / 410996\end{array}$ & No sig assn w/ PDR in TIDM & Spanish (147 pts) & Clinically assessed & 62 \\
\hline \multirow[t]{10}{*}{$\mathrm{CHN} 2$} & rs I002630 A allele & Negative assn w/ NPDR (OR & Taiwanese - Han & Clinically assessed & 64 \\
\hline & & $=0.25,95 \% \mathrm{Cl}=0.09-0.73)$ & Chinese - (719 pts) & & \\
\hline & & but not w/ PDR in T2DM & & & \\
\hline & rs I362363 G allele & Negative assn w/ DR (NPDR & & & \\
\hline & & $+\mathrm{PDR})$ in T2DM (OR =0.66, & & & \\
\hline & & $95 \% \mathrm{Cl}=0.44-0.99)$ & & & \\
\hline & rs39059 & No sig assn w/ DR in T2DM & & & \\
\hline & rs2023908 & No sig assn w/ DR in T2DM & & & \\
\hline & rs39059 & No sig assn w/ DR in TIDM & $\begin{array}{l}\text { US, demographics not } \\
\text { reported (I,907 pts) }\end{array}$ & Clinically assessed & 65 \\
\hline & rs39075 & No sig assn w/ DR in TIDM & & & \\
\hline \multirow[t]{9}{*}{ EPO } & rs507392 CC genotype & Negative assn w/ DR & Chinese (792 pts) & Clinically assessed & 67 \\
\hline & & $(P=0.027)$ and $P D R(P=0.002)$ & & & \\
\hline & & in T2DM & & & \\
\hline & rs55I238 CC genotype & Negative assn w/ DR & & & \\
\hline & & $(P=0.016)$ and PDR $(P=0.002)$ & & & \\
\hline & & in T2DM & & & \\
\hline & rs 1617640 & No sig assn between NDR & & & \\
\hline & rs551238 & $\begin{array}{l}\text { or PDR in T2DM } \\
\text { No sig assn } w / D R \text { in T2DM }\end{array}$ & Chinese (500 pts) & Clinically assessed & 48 \\
\hline & $\begin{array}{l}\text { rs } 1617640 \\
\text { rs } 1617640\end{array}$ & $\begin{array}{l}\text { No sig assn w/ DR in T2DM } \\
\text { No sig assn w/ DR in TIDM }\end{array}$ & $\begin{array}{l}\text { US, demographics not } \\
\text { reported (I,907 pts) }\end{array}$ & Clinically assessed & 65 \\
\hline \multirow[t]{10}{*}{$\begin{array}{l}\text { GSTTI and } \\
\text { GSTM I }\end{array}$} & Null genotype in GSTTI & $\begin{array}{l}\text { Positive assn w/ DR } \\
\text { (NPDR + PDR) in T2DM } \\
(P<0.00 \mathrm{I})\end{array}$ & Slovenian (604 pts) & Clinically assessed & 69 \\
\hline & Null genotype in GSTMI & Negative assn $\mathrm{w} / \mathrm{DR}$ & & & \\
\hline & & in T2DM $(P<0.00 \mathrm{I})$ & & & \\
\hline & $\begin{array}{l}\text { Null genotype in GSTTI } \\
\text { Null genotype in GSTMI }\end{array}$ & $\begin{array}{l}\text { No sig assn } w / D R \text { in T2DM } \\
\text { Positive assn } w / D R \text { in T2DM } \\
(P=0.04)\end{array}$ & Iranian (II5 pts) & Clinically assessed & 70 \\
\hline & Null genotype in GSTTI & $\begin{array}{l}\text { Positive assn w/ DR } \\
\text { (4 studies = T2DM, } \\
\text { I study = TIDM; } P<0.000 \text { I) }\end{array}$ & $\begin{array}{l}\text { Caucasian (meta-analysis } \\
\text { of } 5 \text { studies - report } \\
3,563 \text { pts, but actually }\end{array}$ & Not reported & 71 \\
\hline & Null genotype in GSTMI & Positive assn $\mathrm{w} / \mathrm{DR}$ & comprise 3,463 pts based & & \\
\hline & & ( 3 studies $=$ T2DM, & on studies included in & & \\
\hline & & I study = TIDM; $P=0.0005$ ) & meta-analysis) & & \\
\hline & Null genotype in GSTTI & No sig assn w/ DR in T2DM & $\begin{array}{l}\text { Southern Iranian } \\
(605 \text { pts) }\end{array}$ & Clinically assessed & 72 \\
\hline & Null genotype in GSTMI & No sig assn w/ DR in T2DM & & & \\
\hline
\end{tabular}


Table 2 (Continued)

\begin{tabular}{|c|c|c|c|c|c|}
\hline Gene & Polymorphism & $\begin{array}{l}\text { Relation to diabetic } \\
\text { retinopathy and } \\
\text { significance level }\end{array}$ & $\begin{array}{l}\text { Population and } \\
\text { size (number of } \\
\text { participants) }\end{array}$ & $\begin{array}{l}\text { Methodology } \\
\text { (self-reported vs } \\
\text { clinically assessed) }\end{array}$ & References \\
\hline \multirow[t]{5}{*}{ ICAM-I } & $\begin{array}{l}\text { rs5498 (K469E) AA } \\
\text { genotype }\end{array}$ & $\begin{array}{l}\text { Positive assn } w / D R \text { in T2DM } \\
(P=0.012)\end{array}$ & South Indian (356 pts) & Clinically assessed & 74 \\
\hline & $\begin{array}{l}\text { rs5498 (K469E) } \\
(G G+A G \text { vs AA) }\end{array}$ & $\begin{array}{l}\text { Negative assn w/ PDR in } \\
\text { T2DM in Asian pts only } \\
(P=0.016) ; \text { no sig assn w/ DR } \\
\text { in T2DM }\end{array}$ & $\begin{array}{l}\text { Asian (meta-analysis of } \\
7 \text { studies - } 2076 \text { pts); } \\
\text { assn w/ PDR was } \\
\text { found using } 3 \text { studies } \\
\text { comprising I,232 pts }\end{array}$ & Clinically assessed & 75 \\
\hline & $\begin{array}{l}\text { rs I799969 (G24IR or } \\
+24 \mid G / A)\end{array}$ & No sig assn $w / D R$ in T2DM & Chinese (500 pts) & Clinically assessed & 48 \\
\hline & rs5498 (K469E) & $\begin{array}{l}\text { No sig assn w/ DR in DM } \\
\text { (TI and T2) }\end{array}$ & $\begin{array}{l}4 \text { Asian and } 3 \text { Caucasian } \\
\text { (meta-analysis of } 7 \\
\text { studies - } 3,41 \text { I pts) }\end{array}$ & Not reported & 76 \\
\hline & rs5498 (K469E) & No sig assn w/ DR in T2DM & $\begin{array}{l}6 \text { Asian + I Caucasian } \\
\text { study (meta-analysis of } \\
7 \text { studies - 2,003 pts) }\end{array}$ & Not reported & 77 \\
\hline \multirow[t]{2}{*}{ IFN- $\gamma$} & $\begin{array}{l}\text { rs243056I (+874 T/A) } \\
\text { T allele }\end{array}$ & $\begin{array}{l}\text { Positive assn } w / P D R \text { in } \\
\text { T2DM }(P=0.00 \mathrm{I} I)\end{array}$ & $\begin{array}{l}\text { Asian (Indian, Bengali } \\
\text { Hindu - } 493 \text { pts) }\end{array}$ & Clinically assessed & 44 \\
\hline & rs243056I (+874 T/A) & No sig assn w/ DR in T2DM & Brazilian (102 pts) & Clinically assessed & 79 \\
\hline \multirow[t]{5}{*}{ IL- 10} & $\begin{array}{l}\text { rs I800896 }(-1082) \mathrm{G} \\
\text { allele in IL-10 } \\
\text { rs I800795 }(-174 G / C) \\
\text { in IL-6 }\end{array}$ & $\begin{array}{l}\text { Positive assn } w / P D R \text { in } \\
\text { T2DM }(P=0.0048) \\
\text { No sig assn } w / P D R \text { in T2DM }\end{array}$ & Bengali Hindu (493 pts) & Clinically assessed & 80 \\
\hline & $\begin{array}{l}\text { rs I } 800896(-1082 \mathrm{G} / \mathrm{A}) \\
\text { in IL-10 }\end{array}$ & No sig assn w/ DR in T2DM & Brazilian (102 pts) & Clinically assessed & 79 \\
\hline & $\begin{array}{l}\text { rs I80087| }(-8 \mid 9 C / T) \\
\text { in IL-10 }\end{array}$ & No sig assn w/ DR in T2DM & & & \\
\hline & $\begin{array}{l}\mathrm{rs} / 800872(-592 \mathrm{C} / \mathrm{A}) \\
\text { in IL-10 }\end{array}$ & No sig assn w/ DR in T2DM & & & \\
\hline & $\begin{array}{l}\text { rsI } 800795(-174 C / G) \\
\text { in IL-6 }\end{array}$ & No sig assn w/ DR in T2DM & & & \\
\hline \multirow[t]{4}{*}{ MCP-I } & $\begin{array}{l}\text { rs I0246II }(-25 \mid 8 \mathrm{~A} / \mathrm{G}) \\
\text { AA genotype }\end{array}$ & $\begin{array}{l}\text { Positive assn } \mathrm{w} / \mathrm{PDR} \text { in } \\
\text { T2DM }(P=0.009)\end{array}$ & Korean (590 pts) & Clinically assessed & 82 \\
\hline & $\begin{array}{l}\mathrm{rs}|0246| \mathrm{I}(-25 \mid 8 \mathrm{~A} / \mathrm{G}) \\
\mathrm{G} \text { allele }\end{array}$ & $\begin{array}{l}\text { Positive assn w/ PDR } \\
(P=0.02) \text { but not NPDR in } \\
\text { T2DM }\end{array}$ & Han Chinese (I,043 pts) & Clinically assessed & 83 \\
\hline & $\begin{array}{l}\text { rsI0246II }(-25 \mid 8 \mathrm{~A} / \mathrm{G}) \\
\mathrm{G} \text { allele }\end{array}$ & $\begin{array}{l}\text { Increased onset of DR } \\
\text { associated } w / \text { increased } \\
\text { number of } G \text { alleles in T2DM } \\
(P=0.030)\end{array}$ & Japanese (758 pts) & Clinically assessed & 84 \\
\hline & $\begin{array}{l}\text { rsI0246II }(-25 \mid 8 \mathrm{~A} / \mathrm{G}) \\
\mathrm{G} \text { allele }\end{array}$ & $\begin{array}{l}\text { Positive assn w/ PDR } \\
(P=0.007) \text { and NPDR } \\
(P=0.026) \text { in T2DM }\end{array}$ & Han Chinese (5 I7 pts) & Clinically assessed & 85 \\
\hline \multirow[t]{2}{*}{ MnSOD } & $\begin{array}{l}\text { Al6V (C47T) } \\
\text { AV genotype }\end{array}$ & $\begin{array}{l}\text { Positive assn w/ DR } \\
(P<0.000 \mathrm{I}) \text { [Type of DM not } \\
\text { specified in abstract, original } \\
\text { article in Russian] }\end{array}$ & North Iranian (280 pts) & $\begin{array}{l}\text { Not reported in } \\
\text { abstract, original } \\
\text { article in Russian }\end{array}$ & 87 \\
\hline & Al6V (C47T) & $\begin{array}{l}\text { No sig assn w/ DR } \\
\text { in T2DM }\end{array}$ & North Indian (758 pts) & Clinically assessed & 41 \\
\hline \multirow[t]{2}{*}{ PAl-I } & $\begin{array}{l}-6754 G / 5 G \\
4 G 4 G \text { genotype }\end{array}$ & $\begin{array}{l}\text { Positive assn w/ DR in T2DM } \\
\text { in Caucasians }(P=0.003) \text { but } \\
\text { not Asians }\end{array}$ & $\begin{array}{l}\text { Caucasian, Asian, and } \\
\text { Pima Indians (meta- } \\
\text { analysis of } 9 \text { studies } \\
-2,676 \mathrm{pts} \text { ) }\end{array}$ & Not reported & 90 \\
\hline & $-6754 G / 5 G$ & $\begin{array}{l}\text { No sig assn w/ DR in TIDM } \\
\text { (Asian descent) or in T2DM } \\
\text { (European descent) }\end{array}$ & $\begin{array}{l}\text { Asian and European } \\
\text { (meta-analysis of } 10 \\
\text { studies - 5,768 pts) }\end{array}$ & Not reported & 91 \\
\hline
\end{tabular}


Table 2 (Continued)

\begin{tabular}{|c|c|c|c|c|c|}
\hline Gene & Polymorphism & $\begin{array}{l}\text { Relation to diabetic } \\
\text { retinopathy and } \\
\text { significance level }\end{array}$ & $\begin{array}{l}\text { Population and } \\
\text { size (number of } \\
\text { participants) }\end{array}$ & $\begin{array}{l}\text { Methodology } \\
\text { (self-reported vs } \\
\text { clinically assessed) }\end{array}$ & References \\
\hline \multirow[t]{12}{*}{ PPAR $\gamma$} & rsI80I282 (Prol2Ala) & Negative assn $w / D R$ in & 6 Caucasian studies and & Clinically assessed & 94 \\
\hline & I2Ala allele & T2DM in Caucasian subgroup & 2 Asian studies & & \\
\hline & & $(P=0.0 \mathrm{I})$ but not in Asian & (meta-analysis of & & \\
\hline & & subgroup $(P=0.12)$ & 8 studies $-5,170 p t s)$ & & \\
\hline & rs 1801282 (Prol2Ala) & Negative assn w/ PDR & Pakistani (573 pts) & Clinically assessed & 95 \\
\hline & I2Ala allele & $(\mathrm{OR}=0.4,95 \% \mathrm{Cl}=0.2-0.8)$ & & & \\
\hline & & but not NPDR in T2DM & & & \\
\hline & rsI80I282 (Prol2Ala) & $\begin{array}{l}\text { No sig assn w/ DR or PDR } \\
\text { in T2DM }\end{array}$ & Chinese (792 pts) & Clinically assessed & 97 \\
\hline & rs3856806 & $\begin{array}{l}\text { No sig assn w/ DR or PDR } \\
\text { in T2DM }\end{array}$ & & & \\
\hline & rs $12497|9|$ & $\begin{array}{l}\text { No sig assn w/ DR or PDR } \\
\text { in T2DM }\end{array}$ & & & \\
\hline & rs 1801282 (Prol2Ala) & No sig assn w/ DR in TIDM & $\begin{array}{l}\text { US, demographics not } \\
\text { reported (I,907 pts) }\end{array}$ & Clinically assessed & 65 \\
\hline & rs 1801282 (Prol2Ala) & No sig assn w/ DR in TIDM & Finnish $(2,963 \mathrm{pts})$ & Clinically assessed & 96 \\
\hline \multirow[t]{10}{*}{ TCF7L2 } & rs7903146 & $\begin{array}{l}\text { Positive assn } w / D R \text { in T2DM } \\
(P=0.037)\end{array}$ & Italian (325 pts) & Clinically assessed & 99 \\
\hline & rs 12255372 & $\begin{array}{l}\text { Positive assn } w / D R \text { in T2DM } \\
(P=0.014)\end{array}$ & & & \\
\hline & rs7901695 & No sig assn w/ DR in T2DM & & & \\
\hline & rs7903। $46 \mathrm{~T}$ allele & $\begin{array}{l}\text { Positive assn } w / \text { PDR in T2DM } \\
(P=0.00 I) \text { but not in TIDM }\end{array}$ & $\begin{array}{l}\text { Caucasian (I,I39 T2DM } \\
\text { pts and } 789 \text { TIDM pts) }\end{array}$ & Clinically assessed & 100 \\
\hline & rs7903|46 & No sig assn w/ DR in T2DM & $\begin{array}{l}\text { African Americans, } \\
\text { Caucasians, Polish, and } \\
\text { Asian (review of } \\
3 \text { studies + I abstract - } \\
\text { I,000+ pts) }\end{array}$ & Not reported & 102 \\
\hline & rs6585205 & No sig assn w/ DR in T2DM & Chinese (I,129 pts) & $\begin{array}{l}\text { Not reported in } \\
\text { abstract, original } \\
\text { article in Chinese }\end{array}$ & 101 \\
\hline & rs7903I46 & No sig assn w/ DR in T2DM & & & \\
\hline & rsIII96218 & No sig assn w/ DR in T2DM & & & \\
\hline & rs7903|46 & No sig assn w/ DR in TIDM & Finnish (2,963 pts) & Clinically assessed & 96 \\
\hline & rsll| 96205 & $\begin{array}{l}\text { No sig assn w/ DR or PDR } \\
\text { in T2DM }\end{array}$ & Chinese (792 pts) & Clinically assessed & 97 \\
\hline \multirow[t]{10}{*}{ TGF- $\beta I$} & rsI80047I (R25P) & Positive assn w/ DR in T2DM & Brazilian (I02 pts) & Clinically assessed & 79 \\
\hline & (+9I5G/C) G allele & $(P=0.018)$ & & & \\
\hline & rsl982073 (T869C) & No sig assn w/ DR in T2DM & & & \\
\hline & rsl982073 (T869C) & Negative assn w/ DR in & Czech, Polish, and Indian & Clinically assessed & 105 \\
\hline & (LIOP) L allele & T2DM $(P=0.03)$ & $\begin{array}{l}\text { (meta-analysis of } 3 \\
\text { studies - I,I0I pts total) }\end{array}$ & & \\
\hline & rs $1800469(-509 \mathrm{C} / \mathrm{T})$ & No sig assn w/ DR in T2DM & & & \\
\hline & rs I800468 (-800 G/A) & No sig assn w/ DR in T2DM & & & \\
\hline & rsl982073 (T869C) & No sig assn w/ DR in TIDM & $\begin{array}{l}\text { Caucasian } \\
\text { (British - 36I pts) }\end{array}$ & Clinically assessed & 106 \\
\hline & rsI80047I (R25P) & No sig assn w/ DR in TIDM & & & \\
\hline & $(+915 G / C)$ & & & & \\
\hline \multirow[t]{7}{*}{ TLR4 } & rs4986790 (Asp299Gly) & No sig assn w/ DR in T2DM & North Indian (698 pts) & Clinically assessed & 109 \\
\hline & rs498679I (Thr399|le) & No sig assn w/ DR in T2DM & & & \\
\hline & rs1075993| (TLR4_I859) & Positive assn w/ DR in T2DM & & & \\
\hline & AG genotype & $(P=0.04)$ & & & \\
\hline & rs19279|4 (TLR4_2437) & Positive assn w/ DR in T2DM & & & \\
\hline & TC genotype & $(P=0.05)$ & & & \\
\hline & rs19279II (TLR4_7764) & No sig assn w/ DR in T2DM & & & \\
\hline
\end{tabular}


Table 2 (Continued)

\begin{tabular}{|c|c|c|c|c|c|}
\hline Gene & Polymorphism & $\begin{array}{l}\text { Relation to diabetic } \\
\text { retinopathy and } \\
\text { significance level }\end{array}$ & $\begin{array}{l}\text { Population and } \\
\text { size (number of } \\
\text { participants) }\end{array}$ & $\begin{array}{l}\text { Methodology } \\
\text { (self-reported vs } \\
\text { clinically assessed) }\end{array}$ & References \\
\hline & rs 1927914 C allele & $\begin{array}{l}\text { Positive assn } w / D R \text { in T2DM } \\
(P=0.018)\end{array}$ & Han Chinese (5 I0 pts) & Clinically assessed & 110 \\
\hline & rs10759931 & No sig assn w/ DR in T2DM & & & \\
\hline & (TLR4_I859) & & & & \\
\hline & rs19279II (TLR4_7764) & No sig assn w/ DR in T2DM & & & \\
\hline \multirow[t]{10}{*}{ TNF- $\alpha$} & rs I800629 (TNF-308 & Positive assn $\mathrm{w} / \mathrm{PDR}$ & Caucasian-Brazilian & Clinically assessed & 112 \\
\hline & G/A) A allele & in T2DM $(P=0.035)$ & (745 pts) & & \\
\hline & rs36I525 (TNF-238) & Positive assn w/ PDR & Bengali Hindu (493 pts) & Clinically assessed & 80 \\
\hline & A allele & in T2DM $(P=0.000 \mathrm{I})$ & & & \\
\hline & rs I800629 (TNF-308 G/A) & No sig assn w/ PDR in T2DM & & & \\
\hline & rs 1800629 & No sig assn w/ DR in T2DM & Indian (Punjab; NW & Clinically assessed & 57 \\
\hline & (TNF-308 G/A) & & India - 672 pts) & & \\
\hline & rs|800629 & No sig assn w/ DR in T2DM & Brazilian (I02 pts) & Clinically assessed & 79 \\
\hline & (TNF-308 G/A) & & & & \\
\hline & $\begin{array}{l}\text { rsl800629 } \\
(\mathrm{TNF}-308 \mathrm{G} / \mathrm{A})\end{array}$ & No sig assn w/ DR in T2DM & $\begin{array}{l}\text { Asian and European } \\
\text { (meta-analysis of } \\
5 \text { studies - } 304 \text { l pts) }\end{array}$ & Not reported & 113 \\
\hline \multirow[t]{7}{*}{$\begin{array}{l}\text { UCPI and } \\
\text { UCP2 }\end{array}$} & $\begin{array}{l}\text { rsI800592 (-3826A/G), } \\
\text { G/G genotype in UCPI }\end{array}$ & $\begin{array}{l}\text { Positive assn } w / D R \text { in TIDM } \\
(P=0.043)\end{array}$ & Brazilian (257 pts) & Clinically assessed & 115 \\
\hline & $\begin{array}{l}\text { rsI800592 (-3826A/G), } \\
\text { G/G genotype in UCPI }\end{array}$ & $\begin{array}{l}\text { Positive assn w/ PDR } \\
(P=0.03) \text { but not NPDR } \\
\text { in T2DM }\end{array}$ & Chinese (792 pts) & Clinically assessed & 97 \\
\hline & rs659366 866 G allele & Positive assn w/ PDR & Chinese (958 pts) & Clinically assessed & 116 \\
\hline & in promoter region & $(P=0.016)$ but not NPDR & & & \\
\hline & in UCP2 & in T2DM & & & \\
\hline & rs660339 Ala55Val & No sig assn w/ PDR/NPDR & & & \\
\hline & in exon 4 in UCP2 & in T2DM & & & \\
\hline
\end{tabular}

Abbreviations: T2DM, type 2 diabetes mellitus; DR, diabetic retinopathy; NW, north west; CFH, complement factor H; CFB, complement factor B; PDR, proliferative diabetic retinopathy; CHN2, chimerin 2; NPDR, nonproliferative diabetic retinopathy; OR, odds ratio; Cl, confidence interval; EPO, erythropoietin; GSTTI, glutathione S-transferase theta I; GSTMI, glutathione S-transferase mu I; ICAM-I, intercellular adhesion molecule-I; TIDM, type I diabetes mellitus; IFN- $\gamma$, interferon gamma; IL-6, interleukin-6; IL-I0, interleukin-I0; MCP-I, monocyte chemoattractant protein-I; PAI-I, plasminogen activator inhibitor-I; PPAR $\gamma$, peroxisome proliferator-activated receptor gamma; TCF7L2, transcription factor 7-like-2; TGF- $\beta$ I, transforming growth factor beta I; TLR4, toll-like receptor 4; TNF- $\alpha$, tumor necrosis factor alpha; MnSOD, manganese superoxide dismutase; UCPI, uncoupling protein I; UCP2, uncoupling protein 2; assn, association; sig, significant; pts, participants; w/, with.

Table 3 Candidate gene studies with no reported associations

\begin{tabular}{|c|c|c|c|c|c|}
\hline Gene & Polymorphism & $\begin{array}{l}\text { Relation to diabetic } \\
\text { retinopathy and } \\
\text { significance level }\end{array}$ & $\begin{array}{l}\text { Population and size } \\
\text { (number of } \\
\text { participants) }\end{array}$ & $\begin{array}{l}\text { Methodology } \\
\text { (self-reported vs } \\
\text { clinically assessed) } \\
\end{array}$ & References \\
\hline \multirow[t]{2}{*}{ HHEX } & rs7923837 & No sig assn w/ DR in T2DM & Chinese (I,I29 pts) & $\begin{array}{l}\text { Not reported in } \\
\text { abstract, original } \\
\text { article in Chinese }\end{array}$ & 101 \\
\hline & rsIIII875 & No sig assn w/ DR in TIDM & Finnish (2,963 pts) & Clinically assessed & 96 \\
\hline \multirow[t]{6}{*}{ SLC } & rsII55847I & No sig assn w/ DR in T2DM & Chinese (I,I29 pts) & $\begin{array}{l}\text { Not reported in } \\
\text { abstract, original } \\
\text { article in Chinese }\end{array}$ & 101 \\
\hline & rs|3266634 & No sig assn $w / D R$ in T2DM & & & \\
\hline & rs3802177 & No sig assn w/ DR in T2DM & & & \\
\hline & rsI3266634 in SLC30A8 & No sig assn w/ DR in TIDM & Finnish (2,963 pts) & Clinically assessed & 96 \\
\hline & SLC2AI 26I77A/G & No sig assn w/ DR in T2DM & Malaysian (2II pts) & Clinically assessed & 119 \\
\hline & rsI3266634 in SLC30A8 & No sig assn w/ DR in T2DM & $\begin{array}{l}\text { Chinese, Malaysian, and } \\
\text { Asian Indians of Singapore } \\
\text { (GWAS of } 6,682 \mathrm{pts} \text { ) }\end{array}$ & Clinically assessed & 120 \\
\hline
\end{tabular}

Abbreviations: HHEX, hematopoietically expressed homeobox; DR, diabetic retinopathy; T2DM, type 2 diabetes mellitus; TIDM, type I diabetes mellitus; SLC, solute carrier; GWAS, genome-wide association study; assn, association; sig, significant; pts, participants. 
A series of 577 Slovenian patients reported that the A allele of 27VNTR $(4 \mathrm{a} / \mathrm{b})$ was significantly associated with PDR in type 2 diabetes $(P=0.01) .{ }^{34}$ Other studies, however, reported no significant associations between eNOS polymorphisms and DR in type 2 diabetes. ${ }^{35-37}$

\section{RAGE}

RAGE regulates oxidative stress and endothelial function in type 2 diabetes. ${ }^{38} \mathrm{~A}$ series of 577 Malaysian patients reported no associations between the $-429 \mathrm{~T} / \mathrm{C}$ polymorphism or the $-374 \mathrm{~T} / \mathrm{A}$ polymorphism and DR in type 2 diabetes. ${ }^{39}$ A meta-analysis of eleven studies containing a subgroup of seven studies including 3,339 Asian, African, and Caucasian patients reported that the AA genotype of the -374T/A polymorphism was negatively associated with $\mathrm{DR}$ in type 2 diabetes $(\mathrm{OR}=0.64,95 \% \mathrm{CI}=0.42-0.99) .{ }^{40}$ Alternatively, a series of 758 North Indian patients reported a significant association between the homozygous Ser82 genotype of the Gly82Ser polymorphism with DR in type 2 diabetes $(P<0.033) .{ }^{41}$ However, one series of 283 Malaysian patients with type 2 diabetes $^{42}$ and one meta-analysis of over 1,000 patients from 29 studies from the US, Europe, and Asia ${ }^{43}$ reported no associations between $R A G E$ polymorphisms and DR.

\section{VEGF}

The best studied gene in the context of DR is $V E G F$. VEGF is involved in the pathogenesis of PDR and diabetic macular edema, and anti-VEGF drugs have become widely used in the treatment of DR. Four well-studied polymorphisms include rs833061 (-460T/C), rs699947 (-2578C/A), rs2010963 $[(405 \mathrm{G} / \mathrm{C})$ and $(634 \mathrm{G} / \mathrm{C})]$, and rs3025039 (+936C/T).

\section{rs83306I (-460T/C)}

A study of 493 Bengali Hindu patients reported a significant association between the $\mathrm{C}$ allele and PDR in type 2 diabetes $(P=0.0043)$, and a significant negative association between the TT genotype and PDR $(P=0.0126) .{ }^{44}$ An 11 -study metaanalysis comprising six studies (1,654 patients of Asian and Caucasian backgrounds) also reported that the $\mathrm{C}$ allele was significantly associated with $\operatorname{PDR}(P=0.02)$ and DR $(P=0.02)$ in type 2 diabetes. ${ }^{45}$ Another 11 -study meta-analysis including three relevant studies of the rs 833061 polymorphism (746 patients of Asian background) also reported that rs833061 was significantly associated with DR in type 2 diabetes $(P=0.02) .{ }^{46}$ However, a study of 376 Han Chinese patients reported that the $\mathrm{C}$ allele was negatively associated with nonPDR $(P=0.013)$, but there was no association with PDR. ${ }^{47}$
A separate series of 500 Chinese patients reported no association with DR in type 2 diabetes. ${ }^{48}$

\section{rs699947 (-2578C/A)}

A meta-analysis including eight studies (2,402 patients of Asian and European backgrounds) reported that rs699947 was significantly associated with DR in type 2 diabetes. ${ }^{49}$ A study of 500 Chinese patients also reported that this polymorphism was significantly associated with DR in type 2 diabetes $(\mathrm{OR}=3.54,95 \% \mathrm{CI}=1.12-11.19) .{ }^{48} \mathrm{~A}$ meta-analysis of 1,702 patients $(1,124$ of which were Asian) from six studies reported that rs699947 was significantly associated with DR in type 2 diabetes in Asian $(P=0.0002)$ but not Caucasian patients. ${ }^{50}$ A study of 148 Egyptian patients reported a significant association between this polymorphism and DR in patients having diabetes (type unspecified) for 20 years or more $(P<0.001) .{ }^{51}$ However, a 6-study meta-analysis of 2,208 patients (both type 1 and type 2 ) from Caucasian and Asian backgrounds, ${ }^{45}$ an 11 -study meta-analysis including six relevant studies of 1,868 patients with type 2 diabetes from Caucasian and Asian backgrounds, ${ }^{46}$ and a series of 1,040 Chinese patients with type 2 diabetes $^{52}$ reported no associations.

\section{rs2010963 [(405G/C) and (634 G/C)]}

A study of 372 Bengali Hindu patients reported that the $405 \mathrm{C}$ allele was significantly associated with PDR $(P=0.0007)$ but not nonproliferative diabetic retinopathy (NPDR) in type 2 diabetes. ${ }^{53}$ A meta-analysis comprising nine studies of 2,947 patients (mixed populations) ${ }^{54}$ also reported a significant association of rs2010963 with DR in type 2 diabetes $(P=0.03)$, but this result was refuted by a 7 -study meta-analysis of 2,104 patients with type 2 diabetes of Asian and Caucasian backgrounds. ${ }^{46}$

\section{rs3025039 (+936C/T)}

A meta-analysis including four studies and 1,147 Asian patients reported a significant association between rs3025039 and DR in type 2 diabetes $(P=0.01) .{ }^{46}$ A study of 372 Bengali Hindu patients reported that the $\mathrm{T}$ allele was significantly associated with PDR $(P=0.0002)$ but not NDPR in type 2 diabetes. ${ }^{53}$ A study of 1,040 Chinese patients also reported no association between $+936 \mathrm{C} / \mathrm{T}$ and $\mathrm{DR}$ in type 2 diabetes. $^{52}$

\section{Other VEGF polymorphisms}

A study of 2,567 French patients reported no association between the rs6921438 and rs10738760 polymorphisms 
and DR in type 2 diabetes. ${ }^{55}$ A study of 500 Chinese patients reported a significant association between rs13207351 and DR in type 2 diabetes $(\mathrm{OR}=3.76,95 \% \mathrm{CI}=1.21-11.71) .{ }^{48}$ In a series of 372 Bengali Hindu patients, no associations were reported between the rs 1570360 (-1154 G/A) or rs2071559 (-604 A/G) polymorphisms and NPDR or PDR in type 2 diabetes. ${ }^{53}$

\section{Newer candidate genes}

\section{Adiponectin}

Adiponectin, encoded by $A D I P O Q$, is involved in regulating glucose levels as well as fatty acid breakdown. ${ }^{56}$ The rs2241766 (T45G) polymorphism T allele of $A D I P O Q$ was significantly associated with DR in type 2 diabetes in a study of 672 Punjab Indian patients $(P=0.0007),{ }^{57}$ but not in a study of 517 Chinese patients. ${ }^{58}$

\section{Complement factors $\mathrm{H}$ and $\mathrm{B}$}

Complement factors $\mathrm{H}(\mathrm{CFH})$ and $\mathrm{B}(\mathrm{CFB})$, both integral mediators of the alternative pathway of the immune system, have also been investigated. ${ }^{59,60}$ The $C F H$ rs800292 (I62V) A allele was negatively associated with DR in a series of 552 Chinese patients with type 2 diabetes $(P=0.04) .{ }^{61}$ In the same series, the $C F B$ rs1048709 (R150R) A allele was significantly associated with DR in type 2 diabetes $(P=0.035) .{ }^{61}$ In addition, the $C F H$ rs 1410996 polymorphism was not significantly associated with PDR in type 1 diabetes in a series of 147 Spanish patients. ${ }^{62}$

\section{Chimerin 2}

Chimerin 2 activity is involved in cell migration and proliferation. ${ }^{63}$ A study of 719 Han Chinese patients reported that the A allele of $\mathrm{rs} 1002630$ (OR $=0.25,95 \%$ $\mathrm{CI}=0.09-0.73$ ) and the $\mathrm{G}$ allele of $\mathrm{rs} 1362363$ (OR $=0.66$, $95 \% \mathrm{CI}=0.44-0.99$ ) were both negatively associated with DR in type 2 diabetes. ${ }^{64} \mathrm{~A}$ meta-analysis of two cohorts (Diabetes Control and Complications Trial/Epidemiology of Diabetes Intervention and Complications and Wisconsin Epidemiologic Study of Diabetic Retinopathy) comprising 1,907 patients reported no association between the rs39059 or rs39075 polymorphisms and DR in type 1 diabetes. $^{65}$

\section{Erythropoietin}

Erythropoietin has been reported to stimulate angiogenesis, vasoconstriction-dependent hypertension, and smooth muscle fiber proliferation. ${ }^{66} \mathrm{~A}$ series of 792 Chinese patients reported that the rs507392 and rs551238 CC genotypes were negatively associated with $\mathrm{DR}(P=0.027$ and $P=0.016$, respectively) and $\mathrm{PDR}(P=0.002$ and $P=0.002$, respectively) in type 2 diabetes. ${ }^{67}$ However, other series reported no associations between erythropoietin polymorphisms and DR. ${ }^{48,65}$

\section{Glutathione S-transferase theta I and glutathione S-transferase mu I}

Glutathione S-transferase theta 1 (GSTT1) and glutathione S-transferase mu 1 (GSTM1) neutralize toxins and products of oxidative stress. ${ }^{68}$ A study of 604 Slovenian patients reported a significant association between the GSTT1 null genotype and DR in type 2 diabetes $(P<0.001)$ and also reported that the GSTM1 null genotype was negatively associated with DR in type 2 diabetes $(P<0.001) .{ }^{69}$ A series of 115 Iranian patients reported a significant association between the GSTM1 null genotype and DR in type 2 diabetes $(P=0.04){ }^{70}$ A meta-analysis of 3,463 subjects from multiple studies reported that both null genotypes were significantly associated with DR in type 1 and type 2 diabetes ( $P<0.0001$ for GSTT1 null genotype, $P=0.0005$ for GSTM1 null genotype). ${ }^{71}$ However, a series of 605 Southern Iranian patients reported no associations between null genotypes in GSTT1 or GSTM1 and DR in type 2 diabetes. ${ }^{72}$

\section{Intercellular adhesion molecule- I}

Intercellular adhesion molecule-1 (ICAM-1) binds integrins and is normally expressed by immune cells and endothelial cells; it participates in Class I major histocompatibility complex-mediated antigen processing/presentation. ${ }^{73}$ The AA genotype of ICAM-1 rs5498 (K469E) polymorphism was significantly associated with DR in a cohort of 356 South Indian patients with type 2 diabetes $(P=0.012) .{ }^{74}$ In addition, a meta-analysis of three studies comprising 1,232 Asian patients reported a significant negative association between the ICAM-1 rs5498 (K469E) GG genotype and PDR in type 2 diabetes $(P=0.016) .{ }^{75}$ However, a series of 500 Chinese patients with type 2 diabetes, ${ }^{48}$ a meta-analysis of seven studies including 3,411 Asian and Caucasian patients with type 2 diabetes, ${ }^{76}$ and a meta-analysis of seven studies including 2,003 Asian and Caucasian patients with type 2 diabetes $^{77}$ have reported no associations between ICAM-1 polymorphisms and DR.

\section{Interferon gamma}

Interferon gamma (IFN- $\gamma$ ) is a soluble cytokine with antiviral, immunoregulatory, and antitumor/antiproliferative properties and is a potent activator of macrophages. ${ }^{78}$ A study of 
493 Bengali Hindu Indians reported a significant association between the $I F N-\gamma$ rs $2430561(+874 \mathrm{~T} / \mathrm{A}) \mathrm{T}$ allele and PDR in type 2 diabetes $(P=0.0011) .{ }^{44}$ However, a study of 102 Brazilian patients reported no association between the same polymorphism and DR in type 2 diabetes. ${ }^{79}$

\section{Interleukin-6 and interleukin-10}

Polymorphisms in interleukin-6 (IL-6) and interleukin-10 (IL-10) were also investigated. The rs1800896 (-1082) $\mathrm{G}$ allele in IL-10 was significantly associated with PDR in a study of 493 Bengali Hindu patients with type 2 diabetes $(P=0.0048) .{ }^{80}$ However, another study of 102 Brazilian patients reported that this polymorphism, plus two others in IL-10 [rs1800871 (-819 C/T) and rs1800872 (-592 C/A)] and one in $I L-6$ [rs1800795 (-174 C/G)], did not associate with DR in type 2 diabetes. ${ }^{79}$

\section{Monocyte chemoattractant protein-I}

Monocyte chemoattractant protein-1 (MCP-1) is a chemokine specific for monocytes and basophils. ${ }^{81}$ A series of 590 Korean patients reported a significant association between MCP-1 rs1024611 (-2518 A/G) AA genotype and PDR in type 2 diabetes $(P=0.009) .{ }^{82}$ Alternatively, a study of 1,043 Han Chinese patients reported that the $\mathrm{G}$ allele of the same polymorphism was significantly associated with high-risk PDR in type 2 diabetes $(P=0.02)$, although no association was reported with NDPR. ${ }^{83}$ Two subsequent studies of 758 Japanese patients with type 2 diabetes $(P=0.030)^{84}$ and 517 Han Chinese patients with type 2 diabetes $(P=0.026)^{85}$ also reported that the $\mathrm{G}$ allele, not the A allele, was significantly associated with DR.

\section{Manganese superoxide dismutase}

Manganese superoxide dismutase binds superoxide byproducts from oxidative phosphorylation. ${ }^{86}$ A study of 280 Northern Iranian patients reported that the A16V (C47T) polymorphism AV genotype was significantly associated with DR $(P<0.0001),{ }^{87}$ although a series of 758 Northern Indian patients reported no association between this polymorphism and DR in type 2 diabetes. ${ }^{41}$

\section{Plasminogen activator inhibitor-I}

Plasminogen activator inhibitor-1 is the main inhibitor of tissue plasminogen activator and plays a major role in the regulation of intravascular fibrinolysis. ${ }^{88}$ Impaired fibrinolysis is involved in the pathogenesis of DR in patients with type 2 diabetes. ${ }^{89}$ A subgroup analysis of a meta-analysis comprising five studies of 1,936 Caucasian patients reported that the $6754 \mathrm{G} / 5 \mathrm{G}$ polymorphism was significantly associated with DR in type 2 diabetes $(P=0.003)$; this association was not observed in the overall 9-study analysis of 2,676 patients of Caucasian, Asian, and Pima Indian backgrounds. ${ }^{90}$ A separate meta-analysis comprising ten studies of 5,768 type 1 and type 2 diabetic patients of Asian and European descents, respectively, reported no significant associations with DR. ${ }^{91}$

\section{Peroxisome proliferator-activated receptor gamma}

Peroxisome proliferator-activated receptor gamma is a regulator of adipocyte differentiation ${ }^{92}$ and has been implicated in the pathology of obesity, diabetes, and other disorders. ${ }^{93}$ A meta-analysis comprising eight studies of 5,170 Caucasian and Asian patients reported that the rs1801282 (Pro12Ala) polymorphism Ala allele was negatively associated with DR in type 2 diabetes in Caucasians only $(P=0.01) .{ }^{94}$ Similarly, a series of 573 Pakistani patients also reported a significant negative association between the Ala allele and PDR in type 2 diabetes $(\mathrm{OR}=0.4,95 \% \mathrm{CI}=0.2-0.8) .{ }^{95}$ However, a series of 1,907 patients from the US with type 1 diabetes, ${ }^{65}$ a series of 2,963 Finnish patients with type 1 diabetes, ${ }^{96}$ and a series of 792 Chinese patients with type 2 diabetes $^{97}$ reported no associations.

\section{Transcription factor 7-like 2}

Variants of transcription factor 7-like 2, a protein involved in blood glucose homeostasis, are associated with increased risk for type 2 diabetes. ${ }^{98}$ A series of 325 Italian patients reported significant associations between the rs7903146 $(P=0.037)$ and $\mathrm{rs} 12255372(P=0.014)$ polymorphisms and DR in type 2 diabetes. ${ }^{99}$ A study of 1,139 Caucasian patients with type 2 diabetes and 789 Caucasian patients with type 1 diabetes reported a significant association between the rs7903146 T allele and PDR in type 2 patients only $(P=0.001) .{ }^{100}$ However, a series of 1,129 Chinese patients with type 2 diabetes, ${ }^{101}$ a series of 2,963 Finnish patients with type 1 diabetes, ${ }^{96}$ a series of 792 Chinese patients with type 2 diabetes, ${ }^{97}$ and a meta-analysis of over 1,000 patients from multiple backgrounds with type 2 diabetes $^{102}$ reported no associations.

\section{Transforming growth factor beta I}

Transforming growth factor beta 1 is involved in many cellular functions such as proliferation and differentiation. ${ }^{103,104}$ A study of 102 Brazilians reported that the rs1800471 (R25P) G allele was significantly associated with DR in type 2 diabetes $(P=0.018) .{ }^{79}$ A meta-analysis of 1,101 
patients including patients from multiple ethnic groups reported that the rs1982073 (T869C) L allele was negatively associated with DR in type 2 diabetes $(P=0.03) .{ }^{105}$ However, a study of 361 British Caucasian patients reported no significant associations between the rs 1982073 (T869C) or rs1800471 (R25P) polymorphisms and DR in type 1 diabetes. ${ }^{106}$

\section{Toll-like receptor 4}

Toll-like receptor 4 helps mediate the innate immune response and has been associated with age-related macular degeneration ${ }^{107,108}$ and Behçet's disease. In two series, one of 698 North Indian patients and one of 510 Han Chinese patients, the rs1927914 (TLR4_2437) polymorphism was significantly associated with DR in type 2 diabetes $(P=0.05$, $P=0.018$, respectively). ${ }^{109,110}$ The study of 698 North Indian patients also reported a significant association between the rs10759931 (TLR4_2437) AG genotype and DR in type 2 diabetes. ${ }^{109}$

\section{Tumor necrosis factor alpha}

Tumor necrosis factor alpha (TNF- $\alpha$ ) is involved in the regulation of processes like cell proliferation, differentiation, apoptosis, lipid metabolism, and blood vessel permeability. ${ }^{111}$ A series of 745 Brazilian-Caucasian patients reported that the rs 1800629 (TNF-308 G/A) A allele was significantly associated with PDR in type 2 diabetes $(P=0.035) .{ }^{112}$ Similarly, a study of 493 Bengali Hindu patients reported that the rs361525 (TNF-238) A allele was significantly associated with PDR in type 2 diabetes $(P=0.0001) .{ }^{80}$ However, a study of 672 Punjab Indian patients with type 2 diabetes, ${ }^{57}$ a series of 102 Brazilian patients with type 2 diabetes, ${ }^{79}$ and a meta-analysis of 3,041 patients from Europe and Asia with type 2 diabetes ${ }^{113}$ reported no associations between the rs 1800629 (TNF-308 $\mathrm{G} / \mathrm{A}$ ) polymorphism and DR.

\section{Uncoupling proteins I and 2}

Uncoupling proteins 1 and 2 (UCP1 and UCP2) are involved in regulation of cellular metabolism. ${ }^{114}$ A study of 257 Brazilian patients reported that the rs1800592 (-3826A/G) GG genotype of $U C P 1$ was significantly associated with DR in type 1 diabetes $(P=0.043) .{ }^{115}$ A series of 792 Chinese patients reported that the $\mathrm{rs} 1800592(-3826 \mathrm{~A} / \mathrm{G}) \mathrm{GG}$ genotype of $U C P 1$ was significantly associated with PDR $(P=0.03)$ but not NPDR in type 2 diabetes. ${ }^{97} \mathrm{~A}$ separate series of 958 Chinese patients reported that the rs $659366 \mathrm{G}$ allele of $U C P 2$ was significantly associated with PDR $(P=0.016)$ but not NPDR in type 2 diabetes. ${ }^{116}$

\section{Candidate genes with no reported associations Hematopoietically expressed homeobox}

Hematopoietically expressed homeobox is involved in embryogenesis, cellular transcriptional misregulation, and pancreatic $\beta$-cell development. ${ }^{117}$ Two studies investigated the rs7923837 polymorphism in 1,129 type 2 diabetic Chinese patients ${ }^{101}$ and rs 1111875 polymorphisms in 2,963 type 1 diabetic Finnish patients, ${ }^{96}$ respectively, and reported no associations with DR.

\section{Solute carrier family}

Solute carrier family (SLC) proteins are expressed mainly in the pancreatic islets of Langerhans and play a role in insulin secretion. ${ }^{118}$ A series of 1,129 Chinese patients with type 2 diabetes, ${ }^{101}$ a series of 2,963 Finnish patients with type 1 diabetes, ${ }^{96}$ a series of 211 Malaysian patients with type 2 diabetes, ${ }^{119}$ and a series of 6,682 patients from Singapore with type 2 diabetes ${ }^{120}$ reported no associations between $S L C$ and DR.

In addition to the genes discussed above, many other polymorphisms have been studied. Table 4 summarizes these relatively new candidate genes that may have bearing on DR.

\section{Discussion}

Many individual studies have reported statistically significant associations between various polymorphisms and features of DR. However, many of the results are conflicting and it is difficult to draw definitive conclusions based on the available literature. At this time, there is no confirmed association with any risk allele reported. This may be due to a variety of reasons.

There are multiple challenges in designing a genetic association study, especially with respect to DR. The genetic contribution to DR appears to be relatively modest, requiring larger sample sizes to achieve sufficient statistical power. Determining the number of patients required to achieve sufficient statistical power is complex and is best performed by statisticians or those with experience in this area. In at least some of the studies reviewed here, it is not certain how (or if) power calculations were performed.

Further, DR is a qualitative trait that cannot be easily reduced to a numerical value. The modified Airlie House Classification is a numerical system based on stereoscopic photographs of seven standard fields, resulting in a grade ranging from 10 (no retinopathy) to 85 (severe vitreous hemorrhage or retinal detachment involving the macula). ${ }^{121}$ However, this complex classification system is rarely used 
Table 4 Additional candidate gene studies and findings

\begin{tabular}{|c|c|c|c|c|c|}
\hline Gene & Polymorphism & $\begin{array}{l}\text { Relation to diabetic } \\
\text { retinopathy and } \\
\text { significance level }\end{array}$ & $\begin{array}{l}\text { Population and } \\
\text { size (number of } \\
\text { participants) }\end{array}$ & $\begin{array}{l}\text { Methodology } \\
\text { (self-reported vs } \\
\text { clinically assessed) }\end{array}$ & References \\
\hline CDKALI & rs10946398 & No sig assn w/ DR in T2DM & Chinese (I,I29 pts) & Uncertain & 101 \\
\hline CDKALI & rs77548840 & No sig assn w/ DR in TIDM & Finnish $(2,963 \mathrm{pts})$ & Clinically assessed & 96 \\
\hline CDKALI & rs7756992 & & & & \\
\hline$C D K N 2 A B$ & rsl08II66I & & & & \\
\hline \multirow[t]{2}{*}{ IGF2BP2 } & rs|470579 & No sig assn w/ DR in TIDM & Finnish (2,963 pts) & Clinically assessed & 96 \\
\hline & rs4402960 & & & & \\
\hline HLA-DRBI & $D R B I * 03: 0 I$ allele & $\begin{array}{l}\text { Negative assn w/ DR } \\
\text { in TIDM }(P=0.03)\end{array}$ & Caucasian (425 pts) & Self-reported & 124 \\
\hline HLA-DRBI & $\begin{array}{l}\text { DQAI*05:0IDQBI*02:0I } \\
\text { haplotype }\end{array}$ & $\begin{array}{l}\text { Negative assn w/ DR } \\
\text { in TIDM }(P=0.03 \mathrm{I})\end{array}$ & & & \\
\hline$H L A-B$ & $D R B|* 04: 0|$ allele & No sig assn w/ DR in TIDM & & & \\
\hline $\begin{array}{l}\text { TMEM2 I 7, } \\
\text { MRPL I 4, and GRIK2 } \\
\text { (chromosome 6) }\end{array}$ & Multiple & Associations vary & Chinese (749 pts) & Clinically assessed & 125 \\
\hline $\begin{array}{l}\text { TBCID4-COMMD6- } \\
\text { UCHL3 }\end{array}$ & rs9565I64 & $\begin{array}{l}\text { Positive assn } w / D R \text { in T2DM } \\
\left(P=1.3 \times 10^{-7}\right)\end{array}$ & $\begin{array}{l}\text { Chinese (1007 } \\
\text { pts) but finding } \\
\text { not replicated in } \\
\text { Hispanic cohort } \\
(585 \text { pts })\end{array}$ & Clinically assessed & 126 \\
\hline LRP2-BBS5 & rsI399634 & $\begin{array}{l}\text { Positive assn } w / D R \text { in T2DM } \\
\left(P=2.0 \times 10^{-6}\right)\end{array}$ & & & \\
\hline ARL4C-SH3BP4 & rs238026I & $\begin{array}{l}\text { Positive assn } w / D R \text { in T2DM } \\
\left(P=2.1 \times 10^{-6}\right)\end{array}$ & & & \\
\hline \multirow[t]{6}{*}{ PON } & rs662 (p.Q192R) in PONI & No sig assn w/ DR in DM & $\begin{array}{l}\text { Meta-analysis } \\
\text { combining } 2 \\
\text { Caucasian studies } \\
\text { and } 3 \text { Asian } \\
\text { studies }(6,123 \mathrm{pts}) ; \\
\text { patients were not } \\
\text { stratified by type of } \\
\text { diabetes in analyses }\end{array}$ & Clinically assessed & 127 \\
\hline & rs854560 (p.L55M) in PONI & Positive assn $w / D R$ in & & & \\
\hline & & $\mathrm{DM}(\mathrm{OR}=2.42,95 \%$ & & & \\
\hline & & $\mathrm{Cl}=1.9 \mathrm{I}-3.07)$ & & & \\
\hline & rs7493 (p.S3IIC) in PON2 & No sig assn $w / D R$ in DM & & & \\
\hline & rsI 2026 (p.AI48G) in PON2 & No sig assn $w / D R$ in DM & & & \\
\hline \multirow[t]{2}{*}{$O P G$} & rs20736I8 C allele in exon I & $\begin{array}{l}\text { Positive assn } w / D R \text { in T2DM } \\
(P=0.004)\end{array}$ & Slovenian (645 pts) & Clinically assessed & 128 \\
\hline & rs3134069 in promoter region & No sig assn w/ DR in T2DM & & & \\
\hline $\begin{array}{l}\text { RPSAP37 and } \\
\text { GRAMD3 }\end{array}$ & rs1073203 & $\begin{array}{l}\text { Both "nominally associated" } \\
\text { with DR in TIDM + T2DM } \\
\text { or T2DM alone, but assn lost } \\
\text { upon Bonferroni correction }\end{array}$ & Australian (463 pts) & Clinically assessed & 129 \\
\hline $\begin{array}{l}A R H G A P 22 \text { (intron } \\
\text { region) }\end{array}$ & rs4838605 & & & & \\
\hline $\begin{array}{l}K D R(\text { VEGFR), } \\
A K R I B I, \text { and } P K C-\beta\end{array}$ & $\begin{array}{l}\text { rs207I559 } \\
\text { Multiple SNPs for different } \\
\text { genes }\end{array}$ & No sig assn w/ DR in T2DM & $\begin{array}{l}\text { Chinese } \\
(500 \mathrm{pts})\end{array}$ & Clinically assessed & 48 \\
\hline rs9362054 & $\begin{array}{l}\text { RPI-90LI4.I (intron portion) } \\
\text { adjacent to KIAAI009/QNII } \\
\text { CEPI62 gene }\end{array}$ & $\begin{array}{l}\text { Borderline genome wide } \\
\text { significance } w / D R\left(P=1.4 \times 10^{-7}\right) \\
\text { but not PDR in T2DM }\end{array}$ & $\begin{array}{l}\text { Japanese } \\
(1,986 \mathrm{pts})\end{array}$ & Clinically assessed & 130 \\
\hline VDR & $\begin{array}{l}\text { rs2228570 (Fokl:C > T) } \\
\text { TT genotype } \\
\text { rs15444l0 (Bsml:G > A) } \\
\text { rs7975232 (Apal:A > C) }\end{array}$ & $\begin{array}{l}\text { Positive assn w/ DR in T2DM } \\
(P<0.0 \mathrm{I}) \\
\text { No sig assn } w / D R \text { in T2DM } \\
\text { No sig assn } w / D R \text { in T2DM }\end{array}$ & $\begin{array}{l}\text { Han Chinese } \\
\text { (204 pts) }\end{array}$ & Clinically assessed & $13 \mid$ \\
\hline
\end{tabular}


Table 4 (Continued)

\begin{tabular}{|c|c|c|c|c|c|}
\hline Gene & Polymorphism & $\begin{array}{l}\text { Relation to diabetic } \\
\text { retinopathy and } \\
\text { significance level }\end{array}$ & $\begin{array}{l}\text { Population and } \\
\text { size (number of } \\
\text { participants) }\end{array}$ & $\begin{array}{l}\text { Methodology } \\
\text { (self-reported vs } \\
\text { clinically assessed) }\end{array}$ & References \\
\hline \multirow[t]{3}{*}{ SLMAP } & rs I $7058639 \mathrm{C}$ allele & $\begin{array}{l}\text { Positive assn w/ DR in T2DM } \\
(P=0.009)\end{array}$ & Qatari (342 pts) & Clinically assessed & 132 \\
\hline & rs $1043045 \mathrm{C}>\mathrm{T}$ & No sig assn w/ DR in T2DM & & & \\
\hline & $\operatorname{rs} 1057719 \mathrm{~A}>\mathrm{G}$ & No sig assn $w / D R$ in T2DM & & & \\
\hline Romo-I & rs6060566 & $\begin{array}{l}\text { Positive assn } w / D R \text { in T2DM } \\
(P=0.024)\end{array}$ & Caucasian (806 pts) & Clinically assessed & 133 \\
\hline FABP2 & Ala54Thr allele & $\begin{array}{l}\text { Positive assn w/ DR in T2DM } \\
(P=0.003)\end{array}$ & Chinese ( 810 pts) & Clinically assessed & 134 \\
\hline RAAS genes & $\begin{array}{l}\text { AGT M235T } \\
\text { ACE I/D } \\
\text { ATIR-AII66C }\end{array}$ & $\begin{array}{l}\text { No sig assn w/ DR in both } \\
\text { TIDM and T2DM in "bulk of } \\
\text { assn studies" reviewed }\end{array}$ & $\begin{array}{l}\text { Multiple (review of } \\
73 \text { studies) }\end{array}$ & Not reported & 135 \\
\hline $\begin{array}{l}\text { miR-126 genetic } \\
\text { variant within } \\
\text { EGFL7 }\end{array}$ & rs4636297 A allele & $\begin{array}{l}\text { Positive assn } w / D R \text { in T2DM } \\
(P=0.026)\end{array}$ & Australian (53I pts) & Clinically assessed & 136 \\
\hline KCNJII & rs5219 A allele & $\begin{array}{l}\text { Positive assn } w / D R \text { in T2DM } \\
(P<0.05)\end{array}$ & $\begin{array}{l}\text { Han Chinese } \\
\text { (580 pts) }\end{array}$ & Clinically assessed & 137 \\
\hline $\begin{array}{l}\text { PLXDC2 } \\
\text { (reported as } \\
\text { "closest gene") }\end{array}$ & rs 1571942 & No sig assn $w / D R$ in TIDM & $\begin{array}{l}\text { US studies, patient } \\
\text { demographics not } \\
\text { reported (I,907 pts) }\end{array}$ & Clinically assessed & 65 \\
\hline & rs 12219125 & No sig assn $w / D R$ in TIDM & & & \\
\hline ITGA2 & $\begin{array}{l}\text { Bgl II (+ allele) (in LD w/ } \\
807 T / C \text { poly so treated } \\
\text { as one combined poly) }\end{array}$ & $\begin{array}{l}\text { Positive assn } w / D R \text { in T2DM } \\
(P=0.02)\end{array}$ & $\begin{array}{l}7 \text { studies } \\
\text { (3 Asian studies, } \\
3 \text { Caucasian } \\
\text { studies, and } \\
\text { I mixed study; }\end{array}$ & Clinically assessed & 138 \\
\hline ITGB3 & $\mathrm{PIA} / / \mathrm{A} 2 \mathrm{~A} 2 \mathrm{~A} 2$ genotype & $\begin{array}{l}\text { Negative assn w/ DR in DM } \\
\text { ( } 3 \text { studies = T2DM, I study } \\
=\text { both TIDM and T2DM; } \\
P=0.002 \text { ) }\end{array}$ & $\begin{array}{l}\text { I,I53 pts total) } \\
4 \text { studies } \\
\text { (3 Caucasian studies } \\
\text { and I Asian study; } \\
\text { I,908 pts total) } \\
\text { (meta-analysis of } 9 \\
\text { studies - 3,007 pts) }\end{array}$ & & \\
\hline$E L$ & $\begin{array}{l}\text { rs20008I3 584C }>\text { T TT } \\
\text { genotype }\end{array}$ & $\begin{array}{l}\text { Positive assn w/ "severe" } \\
\text { NPDR in T2DM (OR =4.3, } \\
95 \% \mathrm{Cl}=1.4-13.1)\end{array}$ & French (287 pts) & Clinically assessed & 139 \\
\hline IGF-I & $\begin{array}{l}-383 \mathrm{C} / \mathrm{T} \\
-1089 \mathrm{C} / \mathrm{T}\end{array}$ & $\begin{array}{l}\text { No sig assn w/ DR in TIDM } \\
\text { No sig assn w/ DR in TIDM }\end{array}$ & $\begin{array}{l}\text { Caucasian } \\
\text { (British - 36I pts) }\end{array}$ & Clinically assessed & 106 \\
\hline p22phox (CYBA) & rs4673 (p22phox 242C > T) & No sig assn/DR in T2DM & $\begin{array}{l}\text { South Indian } \\
\text { ( } 311 \text { pts) }\end{array}$ & Clinically assessed & 36 \\
\hline PARP-I & rsII364I0 (762Ala allele) & $\begin{array}{l}\text { Negative assn w/ DR } \\
\text { in T2DM }(P=0.01)\end{array}$ & & & \\
\hline$X R C C I$ & rs25487 (399GIn allele) & $\begin{array}{l}\text { Positive assn } w / D R \\
\text { in T2DM }(P=0.02)\end{array}$ & & & \\
\hline$H K I$ & $\begin{array}{l}\text { rsl6926246 } \\
\text { rs7072268 }\end{array}$ & $\begin{array}{l}\text { No sig assn w/ DR in } \\
\text { T2DM reported for all }\end{array}$ & $\begin{array}{l}\text { Chinese, Malaysian, } \\
\text { and Asian Indians of }\end{array}$ & Clinically assessed & 120 \\
\hline ANKI & $\begin{array}{l}\text { rs6474359 } \\
\text { rs4737009 }\end{array}$ & polymorphisms listed & $\begin{array}{l}\text { Singapore (GWAS } \\
\text { of } 6,682 \mathrm{pts} \text { ) }\end{array}$ & & \\
\hline MTNRIB & rs $1387 \mid 53$ & & & & \\
\hline TMPRSS6 & rs85579| & & & & \\
\hline Cytochrome P450 & $\begin{array}{l}\text { CYP2C19 poor metabolizer } \\
\text { genotype }\end{array}$ & $\begin{array}{l}\text { Positive assn w/ DR in } \\
\text { T2DM in females only } \\
(\mathrm{OR}=4.18,95 \% \\
\mathrm{Cl}=1.42-12.26)\end{array}$ & Japanese (383 pts) & Clinically assessed & 140 \\
\hline
\end{tabular}


Table 4 (Continued)

\begin{tabular}{|c|c|c|c|c|c|}
\hline Gene & Polymorphism & $\begin{array}{l}\text { Relation to diabetic } \\
\text { retinopathy and } \\
\text { significance level }\end{array}$ & $\begin{array}{l}\text { Population and } \\
\text { size (number of } \\
\text { participants) }\end{array}$ & $\begin{array}{l}\text { Methodology } \\
\text { (self-reported vs } \\
\text { clinically assessed) } \\
\end{array}$ & References \\
\hline CNRI & $\begin{array}{l}\text { rs } 1049353(\mathrm{GI} 359 \mathrm{~A}) \\
\text { A allele }\end{array}$ & $\begin{array}{l}\text { Positive assn } w / D R \text { in T2DM } \\
(P=0.0005)\end{array}$ & Polish (I,II7 pts) & Clinically assessed & $14 \mid$ \\
\hline $\begin{array}{l}\text { Mitochondrial } \\
\text { ALDH2 }\end{array}$ & ALDH $2 * 2$ allele & $\begin{array}{l}\text { Positive assn } w / D R \text { in T2DM } \\
(P=0.02)\end{array}$ & Japanese (234 pts) & Clinically assessed & 142 \\
\hline MTHFR & C677T TT genotype & $\begin{array}{l}\text { Positive assn } w / \text { history of } \\
\text { DR in DM (TIDM and T2DM } \\
\text { combined) } P=0.039\end{array}$ & Turkish (230 pts) & Clinically assessed & 143 \\
\hline SDH & rs3759890 $(-888 G>C)$ & No sig assn w/ DR in T2DM & $\begin{array}{l}\text { Caucasian-Brazilian } \\
\text { (446 pts) }\end{array}$ & Clinically assessed & 144 \\
\hline ARMS2 & rs10490924 & No sig assn w/ DR in TIDM & Spanish (147 pts) & Clinically assessed & 62 \\
\hline
\end{tabular}

Abbreviations: PON, paraoxonase; OR, odds ratio; $\mathrm{Cl}$, confidence interval; OPG, osteoprotegerin; KDR, kinase insert domain receptor; VEGFR, vascular endothelial growth factor receptor; SNP, single nucleotide polymorphism; VDR, vitamin D receptor; SLMAP, sarcolemma associated protein; FABP2, fatty acid binding protein-2; Romo-I, reactive oxygen species modulator I; FABP2, fatty acid binding protein-2; EL, endothelial lipase; IGF-I, insulin-like growth factor I; GWAS, genome-wide association study; CNRI, cannabinoid type I receptor gene; ALDH2, aldehyde dehydrogenase 2; MTHFR, methylenetetrahydrofolate reductase; SDH, sorbitol dehydrogenase; DR, diabetic retinopathy; assn, association; sig, significant; w/, with; pts, participants; T2DM, type 2 diabetes mellitus; TIDM, type I diabetes mellitus; LD, linkage disequilibrium; PDR, proliferative diabetic retinopathy.

today. Specific clinical end points such as any DR, NPDR, PDR, or diabetic macular edema may differ across studies. In addition, some patients have retinal changes that mimic early DR, which may further confound studies. ${ }^{122,123}$

Type 2 diabetes mellitus is associated with relatively late disease onset as well as reduced life span, so the parents of patients may not be available for study. ${ }^{3}$ There is likely substantial heterogeneity within individual studies, including duration of diabetes, age at first diagnosis (if known), strictness of metabolic control, and comorbidities such as hypertension, hypercholesterolemia, and others. In addition, there is likely substantial heterogeneity across different studies, due to underlying differences in study populations.

Different studies were conducted on different continents with patients of different races and ethnicities. Further, multiple meta-analyses combined these studies in different ways. Some studies used self-reported data, which may introduce bias because patients may be more likely to report severe retinopathy as opposed to milder disease. ${ }^{124}$

At this time, genetic associations with DR are an intriguing area of research, but are not helpful in routine clinical management. As we collect more information about genotype-phenotype correlations, our understanding may increase. Ultimately, this information may help to stratify patients into different risk groups, which may positively impact clinical management decisions. In addition, this information may lead to the investigation of future drug targets.

\section{Disclosure}

Dr Schwartz discloses that he has previously received personal fees from Alimera and Bausch + Lomb and writing fees from
Vindico. The other authors report no conflicts of interest in this work.

\section{References}

1. National Institute of Diabetes and Digestive and Kidney Diseases. National Diabetes Statistics Fact Sheet: General Information and National Estimates on Diabetes in the United States. Publication No 02-3892. Bethesda, MD: US Department of Health and Human Services, National Institute of Health; 2000.

2. Ruta LM, Magliano DJ, Lemesurier R, Taylor HR, Zimmet PZ, Shaw JE. Prevalence of diabetic retinopathy in type 2 diabetes in developing and developed countries. Diabet Med. 2013;30(4):387-398.

3. Liew G, Klein R, Wong TY. The role of genetics in susceptibility to diabetic retinopathy. Int Ophthalmol Clin. 2009;49(2):35-52.

4. Moss SE, Klein R, Klein BE. Ten-year incidence of visual loss in a diabetic population. Ophthalmology. 1994;101(6):1061-1070.

5. Zhang X, Saaddine JB, Chou CF, et al. Prevalence of diabetic retinopathy in the United States, 2005-2008. JAMA. 2010;304(6):649-656.

6. Yau JW, Rogers SL, Kawasaki R, et al. Global prevalence and major risk factors of diabetic retinopathy. Diabetes Care. 2012;35(3):556-564.

7. Wong TY, Klein R, Islam FM, et al. Diabetic retinopathy in a multi-ethnic cohort in the United States. Am J Ophthalmol. 2006;141(3):446-455.

8. Sivaprasad S, Gupta B, Crosby-Nwaobi R, Evans J. Prevalence of diabetic retinopathy in various ethnic groups: a worldwide perspective. Surv Ophthalmol. 2012;57(4):347-370.

9. Looker HC, Nelson RG, Chew E, et al. Genome-wide linkage analyses to identify loci for diabetic retinopathy. Diabetes. 2007;56(4):1160-1166.

10. Hietala K, Forsblom C, Summanen P, Groop PH; FinnDiane Study Group. Heritability of proliferative diabetic retinopathy. Diabetes. 2008; 57(8):2176-2180.

11. Arar NH, Freedman BI, Adler SG, et al. Heritability of the severity of diabetic retinopathy: the FIND-Eye study. Invest Ophthalmol Vis Sci. 2008;49(9):3839-3845.

12. Schwartz SG, Brantley MA Jr, Flynn HW Jr. Genetics and diabetic retinopathy. Curr Diabetes Rev. 2013;9(1):86-92.

13. Uhlmann K, Kovacs P, Boettcher Y, Hammes HP, Paschke R. Genetics of diabetic retinopathy. Exp Clin Endocrinol Diabetes. 2006;114(6): 275-294.

14. Petrash JM. All in the family: aldose reductase and closely related aldo-keto reductases. Cell Mol Life Sci. 2004;61(7-8):737-749.

15. Burg MB, Ferraris JD, Dmitrieva NI. Cellular response to hyperosmotic stresses. Physiol Rev. 2007;87(4):1441-1474. 
16. Wang Y, Ng MC, Lee SC, et al. Phenotypic heterogeneity and associations of two aldose reductase gene polymorphisms with nephropathy and retinopathy in type 2 diabetes. Diabetes Care. 2003;26(8): 2410-2415.

17. Fujisawa T, Ikegami H, Kawaguchi $\mathrm{Y}$, et al. Length rather than a specific allele of dinucleotide repeat in the $5^{\prime}$ upstream region of the aldose reductase gene is associated with diabetic retinopathy. Diabet Med. 1999;16(12):1044-1047.

18. Ichikawa F, Yamada K, Ishiyama-Shigemoto S, Yuan X, Nonaka K. Association of an $(\mathrm{A}-\mathrm{C}) \mathrm{n}$ dinucleotide repeat polymorphic marker at the $5^{\prime}$-region of the aldose reductase gene with retinopathy but not with nephropathy or neuropathy in Japanese patients with type 2 diabetes mellitus. Diabet Med. 1999;16(9):744-748.

19. Ikegishi Y, Tawata M, Aida K, Onaya T. Z-4 allele upstream of the aldose reductase gene is associated with proliferative retinopathy in Japanese patients with NIDDM, and elevated luciferase gene transcription in vitro. Life Sci. 1999;65(20):2061-2070.

20. Kumaramanickavel G, Sripriya S, Ramprasad VL, Upadyay NK, Paul PG, Sharma T. Z-2 aldose reductase allele and diabetic retinopathy in India. Ophthalmic Genet. 2003;24(1):41-48.

21. Uthra S, Raman R, Mukesh BN, et al. Diabetic retinopathy: validation study of ALR2, RAGE, iNOS and TNFB gene variants in a south Indian cohort. Ophthalmic Genet. 2010;31(4):244-251.

22. Olmos P, Futers S, Acosta AM, et al. (AC)23 [Z-2] polymorphism of the aldose reductase gene and fast progression of retinopathy in Chilean type 2 diabetics. Diabetes Res Clin Pract. 2000;47(3):169-176.

23. Richeti F, Noronha RM, Waetge RT, et al. Evaluation of AC(n) and $\mathrm{C}(-106) \mathrm{T}$ polymorphisms of the aldose reductase gene in Brazilian patients with DM1 and susceptibility to diabetic retinopathy. Mol Vis. 2007;13:740-745

24. Li Q, Xie P, Huang J, Gu Y, Zeng W, Song H. Polymorphisms and functions of the aldose reductase gene $5^{\prime}$ regulatory region in Chinese patients with type 2 diabetes mellitus. Chin Med J (Engl). 2002;115(2): 209-213.

25. Park HK, Ahn CW, Lee GT, et al. (AC)(n) polymorphism of aldose reductase gene and diabetic microvascular complications in type 2 diabetes mellitus. Diabetes Res Clin Pract. 2002;55(2):151-157.

26. Santos KG, Tschiedel B, Schneider J, Souto K, Roisenberg I. Diabetic retinopathy in Euro-Brazilian type 2 diabetic patients: relationship with polymorphisms in the aldose reductase, the plasminogen activator inhibitor-1 and the methylenetetrahydrofolate reductase genes. Diabetes Res Clin Pract. 2003;61(2):133-136.

27. Rezaee MR, Amiri AA, Hashemi-Soteh MB, et al. Aldose reductase $\mathrm{C}$-106T gene polymorphism in type 2 diabetics with microangiopathy in Iranian individuals. Indian J Endocrinol Metab. 2015;19(1): 95-99.

28. Deng Y, Yang XF, Gu H, et al. Association of C(-106)T polymorphism in aldose reductase gene with diabetic retinopathy in Chinese patients with type 2 diabetes mellitus. Chin Med Sci J. 2014;29(1):1-6.

29. Zhou M, Zhang P, Xu X, Sun X. The relationship between aldose reductase $\mathrm{C} 106 \mathrm{~T}$ polymorphism and diabetic retinopathy: an updated meta-analysis. Invest Ophthalmol Vis Sci. 2015;56(4):2279-2289.

30. Ozüyaman B, Gödecke A, Küsters S, Kirchhoff E, Scharf RE, Schrader J. Endothelial nitric oxide synthase plays a minor role in inhibition of arterial thrombus formation. Thromb Haemost. 2005;93(6): 1161-1167.

31. Zhao S, Li T, Zheng B, Zheng Z. Nitric oxide synthase 3 (NOS3) 4b/a, $\mathrm{T}-786 \mathrm{C}$ and G894T polymorphisms in association with diabetic retinopathy susceptibility: a meta-analysis. Ophthalmic Genet. 2012;33(4): 200-207.

32. Cheema BS, Kohli HS, Sharma R, Bhansali A, Khullar M. Endothelial nitric oxide synthase gene polymorphism and type 2 diabetic retinopathy among Asian Indians. Acta Diabetol. 2012;49(6):481-488.

33. Qian-Qian Y, Yong Y, Jing Z, et al. Association between a 27-bp variable number of tandem repeat polymorphism in intron 4 of the eNOS gene and risk for diabetic retinopathy type 2 diabetes mellitus: a metaanalysis. Curr Eye Res. 2014;39(10):1052-1058.
34. Cilenšek I, Mankoč S, Globočnik Petrovič M, Petrovič D. The 4a/4a genotype of the VNTR polymorphism for endothelial nitric oxide synthase (eNOS) gene predicts risk for proliferative diabetic retinopathy in Slovenian patients (Caucasians) with type 2 diabetes mellitus. Mol Biol Rep. 2012;39(6):7061-7067.

35. Santos KG, Crispim D, Canani LH, Ferrugem PT, Gross JL, Roisenberg I. Relationship of endothelial nitric oxide synthase (eNOS) gene polymorphisms with diabetic retinopathy in Caucasians with type 2 diabetes. Ophthalmic Genet. 2012;33(1):23-27.

36. Narne P, Ponnaluri KC, Siraj M, Ishaq M. Association analysis of polymorphisms in genes related to oxidative stress in South Indian type 2 diabetic patients with retinopathy. Ophthalmic Genet. 2015:1-8.

37. Ma ZJ, Chen R, Ren HZ, Guo X, Guo J, Chen LM. Association between eNOS $4 \mathrm{~b} / \mathrm{a}$ polymorphism and the risk of diabetic retinopathy in type 2 diabetes mellitus: a meta-analysis. J Diabetes Res. 2014;2014: 549747.

38. Kanková K, Márová I, Záhejský J, et al. Polymorphisms 1704G/T and $2184 \mathrm{~A} / \mathrm{G}$ in the RAGE gene are associated with antioxidant status. Metab Clin Exp. 2001;50(10):1152-1160.

39. Ng ZX, Kuppusamy UR, Tajunisah I, Fong KC, Chua KH. Association analysis of $-429 \mathrm{~T} / \mathrm{C}$ and $-374 \mathrm{~T} / \mathrm{A}$ polymorphisms of receptor of advanced glycation end products (RAGE) gene in Malaysians with type 2 diabetic retinopathy. Diabetes Res Clin Pract. 2012;95(3):372-377.

40. Yuan D, Yuan D, Liu Q. Association of the receptor for advanced glycation end products gene polymorphisms with diabetic retinopathy in type 2 diabetes: a meta-analysis. Ophthalmologica. 2012;227(4):223-232.

41. Vanita V. Association of RAGE (p.Gly82Ser) and MnSOD (p.Val16Ala) polymorphisms with diabetic retinopathy in T2DM patients from north India. Diabetes Res Clin Pract. 2014;104(1):155-162.

42. Ng ZX, Kuppusamy UR, Poh R, et al. Lack of association between Gly82Ser, 1704G/T and 2184A/G of RAGE gene polymorphisms and retinopathy susceptibility in Malaysian diabetic patients. Genet Mol Res. 2012;11(1):455-461.

43. Kang P, Tian C, Jia C. Association of RAGE gene polymorphisms with type 2 diabetes mellitus, diabetic retinopathy and diabetic nephropathy. Gene. 2012;500(1):1-9.

44. Paine SK, Basu A, Mondal LK, et al. Association of vascular endothelial growth factor, transforming growth factor beta, and interferon gamma gene polymorphisms with proliferative diabetic retinopathy in patients with type 2 diabetes. Mol Vis. 2012;18:2749-2757.

45. Gong JY, Sun YH. Association of VEGF gene polymorphisms with diabetic retinopathy: a meta-analysis. PLoS One. 2013;8(12): e84069.

46. Han L, Zhang L, Xing W, et al. The associations between VEGF gene polymorphisms and diabetic retinopathy susceptibility: a meta-analysis of 11 case-control studies. J Diabetes Res. 2014;2014:805801.

47. Yuan Y, Wen Z, Guan Y, et al. The relationships between type 2 diabetic retinopathy and VEGF-634G/C and VEGF-460C/T polymorphisms in Han Chinese subjects. J Diabetes Complications. 2014;28(6): 785-790.

48. Yang X, Deng Y, Gu H, et al. Candidate gene association study for diabetic retinopathy in Chinese patients with type 2 diabetes. Mol Vis. 2014;20:200-214

49. Lu Y, Ge Y, Shi Y, Yin J, Huang Z. Two polymorphisms (rs699947, rs2010963) in the VEGFA gene and diabetic retinopathy: an updated meta-analysis. BMC Ophthalmol. 2013;13:56.

50. Wang H, Cheng JW, Zhu LS, et al. Meta-analysis of association between the $-2578 \mathrm{C} / \mathrm{A}$ polymorphism of the vascular endothelial growth factor and retinopathy in type 2 diabetes in Asians and Caucasians. Ophthalmic Res. 2014;52(1):1-8.

51. Shahin RM, Abdelhakim MA, Owid ME, El-Nady M. A study of VEGF gene polymorphism in Egyptian patients with diabetic retinopathy. Ophthalmic Genet. 2015:1-6.

52. Fan X, Wu Q, Li Y, et al. Association of polymorphisms in the vascular endothelial growth factor gene and its serum levels with diabetic retinopathy in Chinese patients with type 2 diabetes: a cross-sectional study. Chin Med J. 2014;127(4):651-657. 
53. Choudhuri S, Chowdhury IH, Das $\mathrm{S}$, et al. Role of NF- $\kappa \mathrm{B}$ activation and VEGF gene polymorphisms in VEGF up regulation in nonproliferative and proliferative diabetic retinopathy. Mol Cell Biochem. 2015;405(1-2):265-279.

54. Qiu M, Xiong W, Liao H, Li F. VEGF -634G $>$ C polymorphism and diabetic retinopathy risk: a meta-analysis. Gene. 2013;518(2): 310-315.

55. Bonnefond A, Saulnier PJ, Stathopoulou MG, et al. What is the contribution of two genetic variants regulating VEGF levels to type 2 diabetes risk and to microvascular complications? PLoS One. 2013;8(2):e55921.

56. Yamauchi T, Kamon J, Minokoshi Y, et al. Adiponectin stimulates glucose utilization and fatty-acid oxidation by activating AMP-activated protein kinase. Nat Med. 2002;8(11):1288-1295.

57. Sikka R, Raina P, Matharoo K, et al. TNF- $\alpha$ (g. $-308 \mathrm{G}>\mathrm{A}$ ) and ADIPOQ (g.+45T $>\mathrm{G})$ gene polymorphisms in type 2 diabetes and microvascular complications in the region of Punjab (North-West India). Curr Eye Res. 2014;39(10):1042-1051.

58. Li Y, Wu QH, Jiao ML, et al. Gene-environment interaction between adiponectin gene polymorphisms and environmental factors on the risk of diabetic retinopathy. J Diabetes Investig. 2015;6(1):56-66.

59. Nichols EM, Barbour TD, Pappworth IY, et al. An extended minicomplement factor $\mathrm{H}$ molecule ameliorates experimental C3 glomerulopathy. Kidney Int. Epub July 29, 2015.

60. Imamura H, Konomoto T, Tanaka E, et al. Familial C3 glomerulonephritis associated with mutations in the gene for complement factor B. Nephrol Dial Transplant. 2015;30(5):862-864.

61. Wang J, Yang MM, Li YB, Liu GD, Teng Y, Liu XM. Association of $\mathrm{CFH}$ and CFB gene polymorphisms with retinopathy in type 2 diabetic patients. Mediators Inflamm. 2013;2013:748435.

62. Toni M, Hermida J, Toledo E, Goñi MJ, Díez Goñi N. Role of CFH and ARMS2 polymorphisms in retinopathy and coronary artery disease in type 1 diabetes. An Sist Sanit Navar. 2012;35(3):425-432. Sloverian.

63. Yuan S, Miller DW, Barnett GH, Hahn JF, Williams BR. Identification and characterization of human beta 2-chimaerin: association with malignant transformation in astrocytoma. Cancer Res. 1995;55(15):3456-3461.

64. Chen M, Lin WR, Lu CH, et al. Chimerin 2 genetic polymorphisms are associated with non-proliferative diabetic retinopathy in Taiwanese type 2 diabetic patients. J Diabetes Complications. 2014;28(4): 460-463.

65. Hosseini SM, Boright AP, Sun L, et al. The association of previously reported polymorphisms for microvascular complications in a metaanalysis of diabetic retinopathy. Hum Genet. 2015;134(2):247-257.

66. De Lucas Cerrillo AM, Bond WS, Rex TS. Safety and angiogenic effects of systemic gene delivery of a modified erythropoietin. Gene Ther. 2015;22(5):365-373.

67. Song Q, Zhang Y, Wu Y, Zhou F, Qu Y. Association of erythropoietin gene polymorphisms with retinopathy in a Chinese cohort with type 2 diabetes mellitus. Clin Experiment Ophthalmol. 2015;43(6):544-549.

68. Doney AS, Lee S, Leese GP, Morris AD, Palmer CN. Increased cardiovascular morbidity and mortality in type 2 diabetes is associated with the glutathione $\mathrm{S}$ transferase theta-null genotype: a Go-DARTS study. Circulation. 2005;111(22):2927-2934.

69. Cilenšek I, Mankoč S, Petrovič MG, Petrovič D. GSTT1 null genotype is a risk factor for diabetic retinopathy in Caucasians with type 2 diabetes, whereas GSTM1 null genotype might confer protection against retinopathy. Dis Markers. 2012;32(2):93-99.

70. Dadbinpour A, Sheikhha MH, Darbouy M, Afkhami-Ardekani M. Investigating GSTT1 and GSTM1 null genotype as the risk factor of diabetes type 2 retinopathy. J Diabetes Metab Disord. 2013;12(1):48.

71. Sun L, Zhang Y, Xiong Y. GSTM1 and GSTT1 null genotype and diabetic retinopathy: a meta-analysis. Int J Clin Exp Med. 2015;8(2): 1677-1683.

72. Moasser E, Azarpira N, Shirazi B, Saadat M, Geramizadeh B. Genetic polymorphisms of glutathione-s-transferase M1 and T1 genes with risk of diabetic retinopathy in Iranian population. Iran J Basic Med Sci. 2014;17(5):351-356.
73. Rothlein R, Dustin ML, Marlin SD, Springer TA. A human intercellular adhesion molecule (ICAM-1) distinct from LFA-1. J Immunol. 1986; 137(4):1270-1274.

74. Vinita K, Sripriya S, Prathiba K, et al. ICAM-1 K469E polymorphism is a genetic determinant for the clinical risk factors of T2D subjects with retinopathy in Indians: a population-based case-control study. BMJ Open. 2012;2(4).

75. Fan WY, Liu NP. Meta-analysis of association between K469E polymorphism of the ICAM-1 gene and retinopathy in type 2 diabetes. Int J Ophthalmol. 2015;8(3):603-607.

76. Su X, Chen X, Liu L, Chang X, Yu X, Sun K. Intracellular adhesion molecule-1 K469E gene polymorphism and risk of diabetic microvascular complications: a meta-analysis. PLoS One. 2013;8(7):e69940.

77. Sun H, Cong X, Sun R, Wang C, Wang X, Liu Y. Association between the ICAM-1 K469E polymorphism and diabetic retinopathy in type 2 diabetes mellitus: a meta-analysis. Diabetes Res Clin Pract. 2014;104(2):e46-e49.

78. Held TK, Weihua X, Yuan L, Kalvakolanu DV, Cross AS. Gamma interferon augments macrophage activation by lipopolysaccharide by two distinct mechanisms, at the signal transduction level and via an autocrine mechanism involving tumor necrosis factor alpha and interleukin-1. Infect Immun. 1999;67(1):206-212.

79. Rodrigues KF, Pietrani NT, Sandrim VC, et al. Association of a large panel of cytokine gene polymorphisms with complications and comorbidities in type 2 diabetes patients. J Diabetes Res. 2015;2015:605965.

80. Paine SK, Sen A, Choudhuri S, et al. Association of tumor necrosis factor $\alpha$, interleukin 6 , and interleukin 10 promoter polymorphism with proliferative diabetic retinopathy in type 2 diabetic subjects. Retina. 2012;32(6):1197-1203.

81. Deshmane SL, Kremlev S, Amini S, Sawaya BE. Monocyte chemoattractant protein-1 (MCP-1): an overview. J Interferon Cytokine Res. 2009;29(6):313-326.

82. Jeon HJ, Choi HJ, Park BH, Lee YH, Oh T. Association of monocyte chemoattractant protein-1 (MCP-1) 2518A/G polymorphism with proliferative diabetic retinopathy in Korean type 2 diabetes. Yonsei Med J. 2013;54(3):621-625.

83. Kudlacek S, Schieder K, Kölbl H, et al. Use of CA 125 monoclonal antibody to monitor patients with ovarian cancer. Gynecol Oncol. 1989; 35(3):323-329.

84. Ninomiya H, Katakami N, Osonoi T, et al. Association between new onset diabetic retinopathy and monocyte chemoattractant protein-1 (MCP-1) polymorphism in Japanese type 2 diabetes. Diabetes Res Clin Pract. 2015;108(3):e35-e7.

85. Jiang Z, Hennein L, Xu Y, Bao N, Coh P, Tao L. Elevated serum monocyte chemoattractant protein-1 levels and its genetic polymorphism is associated with diabetic retinopathy in Chinese patients with type 2 diabetes. Diabet Med. Epub May 16, 2015.

86. Valenti L, Conte D, Piperno A, et al. The mitochondrial superoxide dismutase $\mathrm{A} 16 \mathrm{~V}$ polymorphism in the cardiomyopathy associated with hereditary haemochromatosis. J Med Genet. 2004;41(12):946-950.

87. Haghighi SF, Salehi Z, Sabouri MR, Abbasi N. Polymorphic variant of MnSOD A16V and risk of diabetic retinopathy. Mol Biol (Mosk). 2015;49(1):114-118. Russian.

88. Sartori MT, Danesin C, Saggiorato G, et al. The PAI-1 gene 4G/5G polymorphism and deep vein thrombosis in patients with inherited thrombophilia. Clin Appl Thromb Hemost. 2003;9(4):299-307.

89. Grant MB, Spoerri PE, Player DW, et al. Plasminogen activator inhibitor (PAI)-1 overexpression in retinal microvessels of PAI-1 transgenic mice. Invest Ophthalmol Vis Sci. 2000;41(8):2296-2302.

90. Zhang T, Pang C, Li N, Zhou E, Zhao K. Plasminogen activator inhibitor-1 4G/5G polymorphism and retinopathy risk in type 2 diabetes: a meta-analysis. BMC Med. 2013;11:1.

91. Xu K, Liu X, Yang F, et al. PAI-1-675 4G/5G polymorphism in association with diabetes and diabetic complications susceptibility: a meta-analysis study. PLoS One. 2013;8(11):e79150.

92. Zhuang H, Zhang X, Zhu C, et al. Molecular mechanisms of PPAR- $\gamma$ governing MSC osteogenic and adipogenic differentiation. Curr Stem Cell Res Ther. Epub May 31, 2015. 
93. Kwon KA, Yun J, Oh SY, et al. Clinical significance of peroxisome proliferator-activated receptor $\gamma$ and TRAP220 in patients with operable colorectal cancer. Cancer Res Treat. Epub June 23, 2015.

94. Ma J, Li Y, Zhou F, Xu X, Guo G, Qu Y. Meta-analysis of association between the Pro12Ala polymorphism of the peroxisome proliferatoractivated receptor- $\gamma 2$ gene and diabetic retinopathy in Caucasians and Asians. Mol Vis. 2012;18:2352-2360.

95. Tariq K, Malik SB, Ali SH, et al. Association of Pro12Ala polymorphism in peroxisome proliferator activated receptor gamma with proliferative diabetic retinopathy. Mol Vis. 2013;19:710-717.

96. Fagerholm E, Ahlqvist E, Forsblom C, et al. SNP in the genomewide association study hotspot on chromosome 9p21 confers susceptibility to diabetic nephropathy in type 1 diabetes. Diabetologia. 2012;55(9):2386-2393.

97. Zhang Y, Meng N, Lv Z, Li H, Qu Y. The gene polymorphisms of UCP1 but not PPAR $\gamma$ and TCF7L2 are associated with diabetic retinopathy in Chinese type 2 diabetes mellitus cases. Acta Ophthalmol. 2015;93(3):e223-e229.

98. Kirchhoff K, Machicao F, Haupt A, et al. Polymorphisms in the TCF7L2, CDKAL1 and SLC30A8 genes are associated with impaired proinsulin conversion. Diabetologia. 2008;51(4):597-601.

99. Ciccacci C, Di Fusco D, Cacciotti L, et al. TCF7L2 gene polymorphisms and type 2 diabetes: association with diabetic retinopathy and cardiovascular autonomic neuropathy. Acta Diabetol. 2013;50(5):789-799.

100. Luo J, Zhao L, Chen AY, et al. TCF7L2 variation and proliferative diabetic retinopathy. Diabetes. 2013;62(7):2613-2617.

101. Fu LL, Lin Y, Yang ZL, Yin YB. Association analysis of genetic polymorphisms of TCF7L2, CDKAL1, SLC30A8, HHEX genes and microvascular complications of type 2 diabetes mellitus. Zhonghua Yi Xue Yi Chuan Xue Za Zhi. 2012;29(2):194-199. Chinese.

102. Sudchada P, Scarpace K. Transcription factor 7-like 2 polymorphisms and diabetic retinopathy: a systematic review. Genet Mol Res. 2014; 13(3):5865-5872.

103. Hoerster R, Muether PS, Vierkotten S, Hermann MM, Kirchhof B, Fauser S. Upregulation of TGF- $\beta 1$ in experimental proliferative vitreoretinopathy is accompanied by epithelial to mesenchymal transition. Graefes Arch Clin Exp Ophthalmol. 2014;252(1):11-16.

104. Huang SS, Huang JS. TGF-beta control of cell proliferation. J Cell Biochem. 2005;96(3):447-462.

105. Liu L, Jiao J, Wang Y, et al. TGF-betal gene polymorphism in association with diabetic retinopathy susceptibility: a systematic review and meta-analysis. PLoS One. 2014;9(4):e94160.

106. Bazzaz JT, Amoli MM, Taheri Z, Larijani B, Pravica V, Hutchinson IV. TGF- $\beta 1$ and IGF-I gene variations in type 1 diabetes microangiopathic complications. J Diabetes Metab Disord. 2014;13(1):45.

107. Zareparsi S, Buraczynska M, Branham KE, et al. Toll-like receptor 4 variant D299G is associated with susceptibility to age-related macular degeneration. Hum Mol Genet. 2005;14(11):1449-1455.

108. Kohno H, Chen Y, Kevany BM, et al. Photoreceptor proteins initiate microglial activation via Toll-like receptor 4 in retinal degeneration mediated by all-trans-retinal. J Biol Chem. 2013;288(21): 15326-15341.

109. Singh K, Kant S, Singh VK, Agrawal NK, Gupta SK, Singh K. Tolllike receptor 4 polymorphisms and their haplotypes modulate the risk of developing diabetic retinopathy in type 2 diabetes patients. Mol Vis. 2014;20:704-713.

110. Xu Y, Jiang Z, Huang J, Meng Q, Coh P, Tao L. The association between toll-like receptor 4 polymorphisms and diabetic retinopathy in Chinese patients with type 2 diabetes. Br J Ophthalmol. 2015;99(9): 1301-1305.

111. Fong LY, Ng CT, Zakaria ZA, et al. Asiaticoside inhibits TNF- $\alpha-$ induced endothelial hyperpermeability of human aortic endothelial cells. Phytother Res. Epub July 14, 2015.

112. Sesti LF, Crispim D, Canani LH, et al. The $-308 \mathrm{G}>$ a polymorphism of the TNF gene is associated with proliferative diabetic retinopathy in Caucasian Brazilians with type 2 diabetes. Invest Ophthalmol Vis Sci. 2015;56(2):1184-1190.
113. Meng N, Zhang Y, Li H, Ma J, Qu Y. Association of tumor necrosis factor alpha promoter polymorphism (TNF- $\alpha 238 \mathrm{G} / \mathrm{A}$ and TNF- $\alpha$ $308 \mathrm{G} / \mathrm{A}$ ) with diabetic mellitus, diabetic retinopathy and diabetic nephropathy: a meta-analysis. Curr Eye Res. 2014;39(2):194-203.

114. Nam M, Cooper MP. Role of energy metabolism in the Brown Fat Gene Program. Front Endocrinol (Lausanne). 2015;6:104.

115. Brondani LA, De Souza BM, Duarte GC, et al. The UCP1 -3826A/G polymorphism is associated with diabetic retinopathy and increased UCP1 and MnSOD2 gene expression in human retina. Invest Ophthalmol Vis Sci. 2012;53(12):7449-7457.

116. Shen $Y$, Wen $Z$, Wang $N$, et al. Investigation of variants in UCP2 in Chinese type 2 diabetes and diabetic retinopathy. PLoS One. 2014; 9(11):e112670.

117. Kershaw RM, Siddiqui YH, Roberts D, Jayaraman PS, Gaston K. $\mathrm{PRH} / \mathrm{HHex}$ inhibits the migration of breast and prostate epithelial cells through direct transcriptional regulation of Endoglin. Oncogene. 2014;33(49):5592-5600.

118. Schweigel-Röntgen M. The families of zinc (SLC30 and SLC39) and copper (SLC31) transporters. Curr Top Membr. 2014;73:321-355.

119. Ng ZX, Kuppusamy UR, Tajunisah I, Fong KC, Chua KH. Investigation of SLC2A1 26177A/G gene polymorphism via high resolution melting curve analysis in Malaysian patients with diabetic retinopathy. J Diabetes Complications. 2012;26(5):388-392.

120. Chen P, Ong RT, Tay WT, et al. A study assessing the association of glycated hemoglobin A1C (HbA1C) associated variants with $\mathrm{HbA} 1 \mathrm{C}$, chronic kidney disease and diabetic retinopathy in populations of Asian ancestry. PLoS One. 2013;8(11):e79767.

121. Wu L, Fernandez-Loaiza P, Sauma J, Hernandez-Bogantes E, Masis M. Classification of diabetic retinopathy and diabetic macular edema. World J Diabetes. 2013;4(6):290-294.

122. Klein R, Klein BE, Moss SE. The relationship of systemic hypertension to changes in the retinal vasculature: the Beaver Dam Eye Study. Trans Am Ophthalmol Soc. 1997;95:329-348.

123. Cugati S, Cikamatana L, Wang JJ, Kifley A, Liew G, Mitchell P. Five-year incidence and progression of vascular retinopathy in persons without diabetes: the Blue Mountains Eye Study. Eye. 2006;20(11):1239-1245.

124. Lipner EM, Tomer Y, Noble JA, et al. HLA class I and II alleles are associated with microvascular complications of type 1 diabetes. Hum Immunol. 2013;74(5):538-544.

125. Lin HJ, Huang YC, Lin JM, Wu JY, Chen LA, Tsai FJ. Association of genes on chromosome 6, GRIK2, TMEM217 and TMEM63B (linked to MRPL14) with diabetic retinopathy. Ophthalmologica. 2013;229(1):54-60.

126. Sheu WH, Kuo JZ, Lee IT, et al. Genome-wide association study in a Chinese population with diabetic retinopathy. Hum Mol Genet. 2013; 22(15):3165-3173.

127. Wang J, Yang MM, Rong SS, Ng TK, Li YB, Liu XM. Association of paraoxonase gene polymorphisms with diabetic nephropathy and retinopathy. Mol Med Rep. 2013;8(6):1845-1851.

128. Mankoč Ramuš S, Kumše T, Globočnik Petrovič M, Petrovič D, Cilenšek I. SNP rs2073618 of the osteoprotegerin gene is associated with diabetic retinopathy in Slovenian patients with type 2 diabetes. Biomed Res Int. 2013;2013:364073.

129. Mcauley AK, Wang JJ, Dirani M, Connell PP, Lamoureux E, Hewitt AW. Replication of genetic loci implicated in diabetic retinopathy. Invest Ophthalmol Vis Sci. 2014;55(3):1666-1671.

130. Awata T, Yamashita H, Kurihara S, et al. A genome-wide association study for diabetic retinopathy in a Japanese population: potential association with a long intergenic non-coding RNA. PLoS One. 2014;9(11): e111715.

131. Zhong X, Du Y, Lei Y, Liu N, Guo Y, Pan T. Effects of vitamin D receptor gene polymorphism and clinical characteristics on risk of diabetic retinopathy in Han Chinese type 2 diabetes patients. Gene. 2015;566(2):212-216.

132. Upadhyay R, Robay A, Fakhro K, et al. Role of SLMAP genetic variants in susceptibility of diabetes and diabetic retinopathy in Qatari population. J Transl Med. 2015;13:61. 
133. Petrovic MG, Kruzliak P, Petrovic D. The rs6060566 of the reactive oxygen species modulator 1 (Romo-1) gene affects Romo-1 expression and the development of diabetic retinopathy in Caucasians with type 2 diabetes. Acta Ophthalmol. Epub March 30, 2015.

134. Li Z, Ni CL, Niu WY, Chang BC, Chen LM. The intestinal fatty acid binding protein-2 Ala54Thr polymorphism is associated with diabetic retinopathy in Chinese population. Diabetol Metab Syndr. 2015;7:23.

135. Rahimi Z, Moradi M, Nasri H. A systematic review of the role of renin angiotensin aldosterone system genes in diabetes mellitus, diabetic retinopathy and diabetic neuropathy. J Res Med Sci. 2014;19(11): 1090-1098.

136. Mcauley AK, Dirani M, Wang JJ, Connell PP, Lamoureux EL, Hewitt AW. A genetic variant regulating miR-126 is associated with sight threatening diabetic retinopathy. Diab Vasc Dis Res. 2015;12(2):133-138.

137. Liu NJ, Wu HH, Li YL, et al. An analysis of the association between a polymorphism of KCNJ11 and diabetic retinopathy in a Chinese Han population. Eur J Med Res. 2015;20:3.

138. Gong JY, Deng DT, Sun YH. Association of platelet glycoprotein receptor alpha2beta1 integrin and glycoprotein IIIa gene polymorphisms with diabetic retinopathy: evidence from 3007 subjects. Curr Eye Res. 2015;40(5):476-483.
139. Arndt C, Leclercq I, Nazeyrollas P, et al. Association of endothelial lipase Thr111Ile polymorphism with proliferative retinopathy in type 2 diabetes patients. Diabetes Metab. 2014;40(6):452-458.

140. Kajiwara A, Saruwatari J, Kita A, et al. Sex differences in the effect of cytochrome P450 2C19 polymorphisms on the risk of diabetic retinopathy: a retrospective longitudinal study in Japanese patients with type 2 diabetes. Pharmacogenet Genomics. 2013;23(12):717-720.

141. Buraczynska M, Wacinski P, Zukowski P, Dragan M, Ksiazek A. Common polymorphism in the cannabinoid type 1 receptor gene (CNR1) is associated with microvascular complications in type 2 diabetes. J Diabetes Complications. 2014;28(1):35-39.

142. Morita K, Saruwatari J, Miyagawa H, et al. Association between aldehyde dehydrogenase 2 polymorphisms and the incidence of diabetic retinopathy among Japanese subjects with type 2 diabetes mellitus. Cardiovasc Diabetol. 2013;12:132.

143. Yigit S, Karakus N, Inanir A. Association of MTHFR gene C677T mutation with diabetic peripheral neuropathy and diabetic retinopathy. Mol Vis. 2013;19:1626-1630.

144. Ferreira FN, Crispim D, Canani LH, Gross JL, Dos Santos KG. Association study of sorbitol dehydrogenase $-888 \mathrm{G}>\mathrm{C}$ polymorphism with type 2 diabetic retinopathy in Caucasian-Brazilians. Exp Eye Res. 2013;115:140-143.
Clinical Ophthalmology

\section{Publish your work in this journal}

Clinical Ophthalmology is an international, peer-reviewed journa covering all subspecialties within ophthalmology. Key topics include: Optometry; Visual science; Pharmacology and drug therapy in eye diseases; Basic Sciences; Primary and Secondary eye care; Patien Safety and Quality of Care Improvements. This journal is indexed on

Submit your manuscript here: http://www.dovepress.com/clinical-ophthalmology-journal

\section{Dovepress}

PubMed Central and CAS, and is the official journal of The Society of Clinical Ophthalmology (SCO). The manuscript management system is completely online and includes a very quick and fair peer-review system, which is all easy to use. Visit http://www.dovepress.com/ testimonials.php to read real quotes from published authors. 